\title{
A CSOK-támogatást igénylők vizsgálata az elö- zetes gyermekvállalás és az ingatlanszerzés mértéke szempontjából egy hitelintézet adatai alapján*
}

\author{
Plöchl Kata-Obádovics Csilla
}

A szerzők egy hitelintézet 2016-2020 közötti adatbázisát vizsgálva arra keresik a választ, hogy a Családi Otthonteremtési Kedvezményre (CSOK) pályázók milyen mértékben veszik igénybe a támogatást elöre vállalt gyermek után, az milyen társadalmi csoportok számára nyújt nélkülözhetetlen segítséget a lakásszerzéshez, és mely jövedelmi szint és ingatlanérték esetén indukálja a leginkább a második otthon megszerzését. Klaszteranalízissel megállapítják, hogy a legszerényebb jövedelemmel és kisértékű ingatlannal rendelkező csoportok körében a legjellemzőbb a gyermek elörevállalása. A támogatás számukra nyújtja a legnagyobb segítséget az otthonteremtésben, a támogatási összegböl viszont kis mértékben részesülnek. Az igénylök 8 százaléka a támogatás segítségével meglévő ingatlanja mellé újabbat vásárolt.

Journal of Economic Literature (JEL) kódok: H31, G51, R21, J13

Kulcsszavak: CSOK, lakástámogatás, családtámogatás, lakásigény, gyermekvállalás

\section{Bevezetés}

Magyarországon az öröklakás tulajdonlásának igen nagy szerepe van már a szocializmus óta. A magyar családok 80 százalékának a lakás a legfóbb vagyontárgya, mely a létbiztonságot és akár több generáció munkájának hozadékát is megtestesítheti. Országunkban az európai hagyományokhoz igazodva - közgazdasági és szociális dimenziót öltve - univerzális redisztribúció valósul meg (Dániel 1997; Dániel 2004; Csermák 2011; Levi 1993; Rothstein 1998; Bényei 2011; Kováts 2007; Békés et al. 2016). Ezzel az állam egy magasabb minőségi színvonalú lakástulajdon kialakításában tölt be allokációs szerepet. A támogatási rendszer az öngondoskodást feltételezve a meglévő magántőke mellé állami forrásokat rendel, hogy a lakáscélok könnyebben elérhetővé váljanak (Sági et al. 2017; Maleque 2019).

\footnotetext{
* A jelen kiadványban megjelenő írások a szerzők nézeteit tartalmazzák, ami nem feltétlenül egyezik a Magyar Nemzeti Bank hivatalos álláspontjával.

Plöchl Kata a Soproni Egyetem Lámfalussy Sándor Közgazdaságtudományi Kar, Széchenyi István Doktori Iskola Phd-hallgatója. E-mail: plochl.kata@gmail.com

Obádovics Csilla a Soproni Egyetem Lámfalussy Sándor Közgazdaságtudományi Kar egyetemi tanára. E-mail: obadovics.csilla@uni-sopron.hu

A magyar nyelvű kézirat első változata 2021. március 11-én érkezett szerkesztőségünkbe.

DOI: http://doi.org/10.25201/HSZ.20.3.80109
} 
A magyar lakáspolitikának voltak igen kiterjedt lakástulajdon-szerzést ösztönző időszakai, és voltak igencsak ínséges időszakok is. Egy-egy kormányzati ciklus alatt meghozott lakáspolitikai intézkedés jóval túlmutat egy-egy választási cikluson. A támogatások elhúzódó, nehezen kalkulálható és különösen nehezen szabályozható mivoltából adódóan igen felelős döntések meghozatala kívánatos.

A támogatási rendszer differenciáltságának mértékéről a vélemények megoszlanak. A nézetek azonban közösek abban, hogy szelektív, hosszú távú és fenntartható támogatási rendszert kell kiépíteni. Ez olyan globális lakásépítési, felújítási, fenntartási és finanszírozási keretben múködhet hatékonyan, amely a mindenkor aktuális lakáshelyzeti adottságokhoz a rövid távú célokon túl egyértelműen ki tudja jelölni a közép- és hosszú távú célokat is a gazdaság minden szereplője számára, figyelembe véve a nemzeti sajátosságokat, a kultúrát és a hagyományokat is (Csermák 2011; Mayo 1993).

Magyarország kormánya 2010-től átfogóan foglalkozik a demográfiai kérdésekkel. A magyar családpolitikának kettős célja van: egyrészt hozzásegíteni a fiatalokat, hogy világra hozhassák gyermekeiket a vágyott számban, másrészt támogatni azokat, akiknek már van gyermekük (Novák 2020). A demográfia ugyanis jelentősen befolyásolja az országok jövőjét (Singhammer 2019). A demográfiai célok fontosságát alátámasztja, hogy Magyarország - de egész Európa - termékenységi rátája, ezáltal a népessége, csökken (Beaujouan et al. 2017; Dorbritz - Ruckdeschel 2007; Neyer et al 2016). A gyermekvállalási kedv élénkülése azonban elősegíti a népességszám növekedését (Sobotka 2017). Lesthaeghe (2011) a lakás meglétét alapvető demográfiai folyamatokra ható tényezőként azonosítja. A lakáspolitika mind a minőségi, mind a mennyiségi lakásteremtés terén pozitiv hatást gyakorol a gyermekek számának növekedésére (Fitoussi et al. 2008). Ha a lakástámogatás kedvező hitelfelvétellel párosul, akkor még nagyobb az ösztönző hatás, ami már - a gyermekes családok városkörnyéki településekre való áramlásán keresztül - pozitívan befolyásolja az agglomerációs népességfolyamatokat (Székely 2020).

\section{A 2016-os új lakáspolitika jellemzői; a bevezetése óta végbement legfontosabb változások}

A magyar gazdaság teljesítményének javulása és a nagyobb költségvetési stabilitás lehetővé tette egy intenzívebb lakáspolitikai akció indítását. Így a 2005 utáni idők szűkre szabott lakáspolitikája után 2016-tól elindult a jelenlegi Családvédelmi Akcióterv. A program nem szakít a korábbi lakáspolitikák törekvéseivel (Hegedüs 2006; Kiss - Vadas 2006; Mádi 2008, 2017), tehát továbbra is kiemelten támogatja az új ingatlan szerzését, de célzottabb figyelmet fordít a használt lakásvásárlásokra és -bővítésekre. Feladata az otthonteremtés mellett a gyermekvállalás ösztönzése (Szikra 2016), az építőipar és az ingatlanpiac fellendítése (Tóth - Horváthné 2018), az elnéptelenedő falvak számának csökkentése. 
A Családok Otthonteremtési Kedvezménye igénybevételének feltételeit az 1. táblázat tartalmazza. E feltételeket a 16/2016¹ és 17/2016² kormányrendelet és változásaik határozzák meg.

\section{1. táblázat}

A CSOK támogatás igénybevételének alapfeltételei és azok változásai 2016-2020 között

\begin{tabular}{|c|c|c|}
\hline FELTÉTEL & \multicolumn{2}{|c|}{ JOGSZABÁLYI ELŐÍRÁS } \\
\hline Igénylő lehet & \multicolumn{2}{|c|}{$\begin{array}{l}\text { - magyar, külföldi állampolgár } \\
\text { - építőközösség tagja, osztatlan közös ingatlan tulajdonosa } \\
\text { (hatályos: } 273 / 2016 \text {. (IX.15.) Korm. rend.) }\end{array}$} \\
\hline Igénylő életkora alapján pályázhat & \multicolumn{2}{|c|}{$\begin{array}{l}\text { - 18-40 év között: meglévő, és előre vállalt gyermek után } \\
\text { - } 40 \text { év felett: csak meglévő gyermekre }\end{array}$} \\
\hline $\begin{array}{l}\text { Igénylő lakhelye, vagy azt igazoló } \\
\text { dokumentum }\end{array}$ & \multicolumn{2}{|c|}{$\begin{array}{l}\text { - bejelentett magyarországi lakhely } \\
\text { - } 3 \text { hónapot meghaladó magyarországi tartózkodási engedély } \\
\text { - bevándorlási engedély Magyarországra }\end{array}$} \\
\hline Igénylő családi állapota & \multicolumn{2}{|c|}{ - házas, élettársi viszony, egyedülálló, elvált, özvegy } \\
\hline Ingatlan komfortfokozata & \multicolumn{2}{|c|}{ - lakhatási igény kielégítésére alkalmas } \\
\hline Munkaviszonnyal kapcsolatos elvárás & \multicolumn{2}{|c|}{$\begin{array}{l}\text { - igényléskor legalább az egyik félnek rendelkeznie kell fennálló } \\
\text { munkaviszonnyal } \\
\text { - kiegészítő tevékenységet végző jogviszony (hatályos: 686/2020. } \\
\text { (XII.29.) Korm. rend.) }\end{array}$} \\
\hline $\begin{array}{l}\text { Minimális, folyamatos (legfeljebb } 30 \\
\text { napos megszakítás melletti) } \\
\text { TB-biztosítotti jogviszony megléte }\end{array}$ & \multicolumn{2}{|c|}{$\begin{array}{l}\text { - 1-2 gyermek esetén } 180 \text { nap } \\
\text { - } 3 \text { gyermek esetén } 365 \text { nap } \\
\text { - használt ingatlannál gyermekszámtól függetlenül } 180 \text { nap } \\
\text { - preferált kistérségen igénylő esetén } 365 \text { nap (hatályos: } \\
\text { 109/2019. (V.13.) Korm. rend.) }\end{array}$} \\
\hline $\begin{array}{l}\text { Támogatás felhasználhatósága } \\
\text { irányulhat }\end{array}$ & \multicolumn{2}{|c|}{$\begin{array}{l}\text { - új ingatlan építésére, vásárlására, használt ingatlan vásárlására } \\
\text { - meglévő ingatlan minimum egy lakószobával való bővítésére (új } \\
\text { - klbetét nélkül) } \\
\text { - prefön lakóegység kialakítása: tetőtér-beépítés, emeletráépítés } \\
\text { (V.13.) Korm. rend.) }\end{array}$} \\
\hline Támogatott gyermek életkora & \multicolumn{2}{|c|}{$\begin{array}{l}\text { - } 24 \text { hetes magzat, maximum 20. életévig } \\
\text { - } 12 \text { hetes magzat, maximum 25. életévig (hatályos: 273/2016. } \\
\text { (IX.15.) Korm. rend.) }\end{array}$} \\
\hline Támogatott gyermeknek minősül & \multicolumn{2}{|c|}{$\begin{array}{l}\text { - saját gyermek, nevelt gyermek, az igénylő által örökbefogadott } \\
\text { gyermek } \\
\text { - min. } 1 \text { éve az igénylő gyámsága alatt lévő gyermek (hatályos: } \\
\text { 273/2016. (IX.15.) Korm. rend.) }\end{array}$} \\
\hline $\begin{array}{l}\text { Tulajdonjoggal a támogatott } \\
\text { ingatlanban rendelkezhet }\end{array}$ & \multicolumn{2}{|c|}{$\begin{array}{l}\text { - csak a támogatott személy/ személyek rendelkezhetnek } \\
\text { - a támogatott személy gyermeke öröklés révén (hatályos: } \\
686 / 2020 . \text { (XII.29.) Korm. rend.) } \\
\text { - házas(élet)társak esetén mindkét félnek együttesen } \\
\text { rendelkeznie kell vele }\end{array}$} \\
\hline Minimális alapterület nagysága & Új lakás (ház) & Használt ingatlan \\
\hline 1 gyermek után & $40(60) \mathrm{m}^{2}$ & $40 \mathrm{~m}^{2}$ \\
\hline 2 gyermek után & $50(70) \mathrm{m}^{2}$ & $50 \mathrm{~m}^{2}$ \\
\hline 3 gyermek után & $60(80) \mathrm{m}^{2}$ & $60 \mathrm{~m}^{2}$ \\
\hline 4 vagy több gyermek után & $60(80) \mathrm{m}^{2}$ & $70 \mathrm{~m}^{2}$ \\
\hline
\end{tabular}

Forrás: 16/2016 (II.10.) és 17/2016 (II.10.) kormányrendeletek és módosításaik alapján

${ }^{1}$ 16/2016. (II.10.) Kormányrendelet az új lakások építéséhez, vásárlásához kapcsolódó állami támogatásról

2 17/2016. (II.10.) Kormányrendelet a használt lakás vásárlásához, bővítéséhez igényelhető családi otthonteremtési kedvezményről 
A támogatás igénybevételére vonatkozóan meghatározásra kerültek kizáró és korlátozó szabályok is, melyek csökkentik az opportunista támogatást igénylők számát (2. táblázat). A korlátozások nagy része a bevezetés óta enyhítésre vagy megszüntetésre került.

\begin{tabular}{|c|c|}
\hline FELTÉTEL & JOGSZABÁLYI ELŐÍRÁS \\
\hline Kizáró oknak minősül & $\begin{array}{l}\text { - köztartozás } \\
\text { - KHR negatív adós lista } \\
\text { - korábbi támogatás feltételeinek nemteljesítése esetén } \\
\text { a támogatási összeg visszafizetésének kötelezettsége }\end{array}$ \\
\hline $\begin{array}{l}\text { Adott gyermek után igénybe vett } \\
\text { támogatás esetén }\end{array}$ & $\begin{array}{l}\text { - a korábban igénybe vett támogatás visszafizetendő, vagy } \\
\text { a gyermekre a támogatás nem igényelhető } \\
\text { - az igénylő számára a kedvezóbb megoldás választható (hatályos: } \\
\text { 46/2019. (III.12.) Korm. rend.) }\end{array}$ \\
\hline $\begin{array}{l}\text { Előre vállalt gyermekre a támogatás } \\
\text { igénylésének előfeltétele }\end{array}$ & $\begin{array}{l}\text { - az igénylő által a CSOK-támogatást megelőzően igénybe vett } \\
\text { támogatás keretében előre vállalt gyermeknek a CSOK- } \\
\text { támogatási igény benyújtásáig meg kell születnie }\end{array}$ \\
\hline $\begin{array}{l}\text { Előre vállalt gyermek teljesítési } \\
\text { határideje }\end{array}$ & $\begin{array}{l}\text { - } 1 \text { gyermek esetén } 4 \text { év } \\
\text { - } 2 \text { gyermek esetén } 8 \text { év } \\
\text { - } 3 \text { gyermek esetén (csak új ingatlannal kapcsolatban választható) } \\
10 \text { év }\end{array}$ \\
\hline $\begin{array}{l}\text { Gyermek előrevállalásának nem } \\
\text { teljesülése, vagy részbeni teljesülése } \\
\text { esetén }\end{array}$ & $\begin{array}{l}\text { - a jogtalanul igénybe vett összeget a Ptk. szerinti késedelmi } \\
\text { kamattal növelten vissza kell téríteni } \\
\text { - három gyermek esetén a támogatási összegen túl a kamat } \\
\text { ötszörösét kell visszafizetni }\end{array}$ \\
\hline Maximális ingatlanár korlátja & $\begin{array}{l}\text { - új ingatlannál nincs korlátozás } \\
\text { - használt ingatlan esetében } 35 \text { millió forint (hatályon kívül } \\
\text { helyezi: 46/2019. (III.12.) Korm. rend.) }\end{array}$ \\
\hline $\begin{array}{l}\text { Meglévő ingatlantulajdonban } \\
\text { meglévő maximális tulajdoni hányad }\end{array}$ & $\begin{array}{l}\text { - új ingatlanra nincs megkötés } \\
\text { - használt ingatlan esetében min. } 50 \text { százalék (hatályon kívül } \\
\text { helyezi: } 26 / 2018 \text {. (II.28.) Korm. rend.) }\end{array}$ \\
\hline $\begin{array}{l}\text { Korábbi támogatással vásárolt } \\
\text { ingatlan értékesítési bevételének } \\
\text { felhasználása }\end{array}$ & $\begin{array}{l}\text { - új ingatlanra nincs megkötés } \\
\text { - használt ingatlan esetén az } 5 \text { éven belül értékesített ingatlanból } \\
\text { befolyt vételár kötelezően visszaforgatandó a jelenlegi } \\
\text { támogatással vásárolt ingatlanba (hatályon kívül helyezi: } \\
26 / 2018 \text {. (II.28.) Korm. rend.) }\end{array}$ \\
\hline $\begin{array}{l}\text { Röghöz kötés a támogatott } \\
\text { ingatlanban }\end{array}$ & $\begin{array}{l}\text { - min. } 10 \text { évig csak a tulajdonosok és a támogatottak bentlakása } \\
\text { - bejegyezhető a tulajdonos cégének székhelyeként (hatályos: } \\
\text { 152/2019. (VI.26.) Korm. rend.) }\end{array}$ \\
\hline
\end{tabular}

Forrás: 16/2016 (II.10.) és 17/2016 (II.10.) kormányrendeletek és módosításaik alapján 
A támogatás mértéke ugyan a meghirdetés óta nem változott, de a preferált kistérségek támogatása, illetve esetükben a komplex cél megvalósulását segítő magas támogatási összeg kedvezően érintette az ide költözni vágyókat (3. táblázat).

\begin{tabular}{|c|c|c|}
\hline \multicolumn{3}{|c|}{$\begin{array}{l}\text { 3. táblázat } \\
\text { A CSOK-támogatás mértéke és annak változása 2016-2020 között }\end{array}$} \\
\hline \multirow[b]{2}{*}{ Nem preferált kistérség esetén } & \multicolumn{2}{|c|}{ TÁMOGATÁS MÉRTÉKE } \\
\hline & Új ingatlan & Használt ingatlan \\
\hline 1 gyermek után & 0,6 millió $\mathrm{Ft}$ & 0,6 millió Ft \\
\hline 2 gyermek után & 2,6 millió Ft & 1,43 millió Ft \\
\hline 3 gyermek után & 10 millió Ft & 2,2 millió Ft \\
\hline 4 vagy több gyermek után & 10 millió Ft & 2,75 millió Ft \\
\hline Preferált kistérség esetén & \multicolumn{2}{|c|}{$\begin{array}{l}\text { - komplex cél esetén az új ingatlanok után járó támogatási } \\
\text { összeggel egyező } \\
\text { - egyedi cél esetén az új ingatlanok után járó támogatási összeg } \\
50 \text { százaléka }\end{array}$} \\
\hline $\begin{array}{l}\text { Adott gyermek után már igénybe } \\
\text { vett támogatás esetén }\end{array}$ & \multicolumn{2}{|c|}{$\begin{array}{l}\text { - a korábban igénybe vett támogatás visszafizetendő, vagy } \\
\text { a gyermekre a támogatás nem igényelhető } \\
\text { - az igénylő számára fentiek közül a kedvezőbb választható } \\
\text { (hatályos: 46/2019. (III.12.) Korm. rend.) }\end{array}$} \\
\hline $\begin{array}{l}\text { Utólag született gyermek } \\
\text { támogatása }\end{array}$ & \multicolumn{2}{|c|}{$\begin{array}{l}\text { - használt ingatlannál minden gyermek után 0,4 millió Ft } \\
\text { - új ingatlan esetén nincs külön támogatás }\end{array}$} \\
\hline Támogatott hitel & \multicolumn{2}{|c|}{$\begin{array}{l}\text { - új ingatlan és } 3 \text { gyermek esetén } 10 \text { millió Ft } \\
\text { - új ingatlan és } 2 \text { gyermek esetén } 10 \text { millió Ft (hatályos: } \\
\text { 209/2018. (IX.13.) Korm. rend.) } \\
\text { - használt ingatlan: } 3 \text { gyermek esetén: } 15 \text { millió Ft, } 2 \text { gyermek } \\
\text { esetén: } 10 \text { millió Ft (hatályos: 46/2019. (III.12.) Korm. rend.) }\end{array}$} \\
\hline
\end{tabular}

Forrás: 16/2016 (II.10.) és 17/2016 (II.10.) kormányrendeletek és módosításaik alapján

\section{Adat és módszer}

A vizsgálat céljai: átfogó képet adni a CSOK-támogatásban részesült családokról a meglévő és előre vállalt gyermekszám és a vásárolt ingatlan típusa szerint; felmérni körükben a gyermekvállalási hajlandóságot; feltárni a jövedelem és ingatlanérték kapcsolat alapján kialakítható igénylői csoportok hasonlóságait és különbségeit. A szekunder információk feldolgozása a lakástámogatásról szóló jogszabályok, szakcikkek keretében történt.

Vizsgálatunkat egy adott hitelintézet 2016-2020 közötti adatbázisából származó, 625, támogatásban részesülő háztartás anonim adatai alapján folytattuk le Nyugat-Magyarország, Közép-Dunántúl, valamint Közép-Magyarország régióra vonatkozóan. Az adatbázisban a vizsgálat szempontjából releváns információ a támogatás igénybevételének ideje, az előre vállalt gyermekek száma, a támogatással érintett ingatlan 
típusa, elhelyezkedése. A család rendelkezésre álló jövedelme, a megvásárolt ingatlan piaci értéke, és egy korábbi ingatlan meglétére vonatkozó információk csak a hitelt felvevők (391 háztartás) esetében állnak rendelkezésre. A dolgozatban a családok méret szerinti szegmentálása minden esetben tartalmazza a meglévő és az előre vállalt gyermekek számát is.

A CSOK-támogatásban részesültek körének általános jellemzését adtuk a gyermekek száma, a gyermekvállalási hajlandóság és a támogatással vásárolt ingatlan típusa figyelembevételével. A CSOK vissza nem térítendő támogatás mellett hitelt igénylők sokaságát a családi jövedelem és az ingatlanérték kapcsolata alapján klaszteranalízissel csoportosítottuk. A változók mérési skálája megegyezik, de az értékterjedelmük jelentősen eltérő, ezért az eljárás előtt standardizáltuk. Mivel a klaszteranalízis érzékeny a kiugró értékekre, a modellalkotást torzító eseteket kizártuk, aminek az eredményeként 371 igénylőre végeztük el az elemzést. A klaszterező eljárás esetében nem beszélhetünk „legjobb” megoldásról (Obádovics 2009), ezért többféle csoportosítási eljárással (centroid-, csoportátlag-, és ward-eljárás) is elvégeztük a hierarchikus klaszteranalízist. A legtöbb egyedi jellemzővel bíró csoportot a centroid módszer adta. A hierarchikus klaszteranalízis alapján a jól elkülöníthető csoportok számát 5-8 közöttire becsültük. A hierarchikus módszer után a K-közép klaszterező eljárással végül a hétklaszteres eredményt fogadtuk el. Az alacsonyabb, ötklaszteres megoldások elvetésre kerültek, mivel így a teljes sokaság 91 százalékát 3 csoport alkotta. A nagy elemszám miatt a csoportjellemzők nem voltak jól meghatározhatók, vizsgálatunk során pedig kiemelt cél az egyediségek feltárása. Hétnél több klaszterszám esetén már voltak egyelemú csoportok is, ezért ezek a megoldások is elvetésre kerültek.

\section{A CSOK-támogatásban részesülők elemzése}

\subsection{Az országos adatok áttekintése a CSOK-igénylök körében}

A Kopp Mária Intézet a Népesedésért és a Családokért (KINCS) által készített elemzések alapján 2020 végéig közel 170 ezren igényelték a támogatást (KINCS 2019, 2020b; Papházi et al. 2021). A vissza nem térítendő támogatásban részesülők 90 százalékának már volt gyermeke a támogatás igénylésekor: 15 százalékuknak egy, 47 százalékuknak kettő, 38 százalékuknak pedig három vagy annál több gyermeke volt vagy lett az előre vállalt gyermekekkel együtt. A CSOK-támogatottak körében a nagycsaládosok aránya többszörösen meghaladja a magyarországi nagycsaládosok (8 százalék) arányát. Az igénylők több mint harmada (59 százaléka egy-, 39 százaléka két-, 2 százalékuk pedig háromgyermekes) vállal még kisbabát. A legnagyobb gyermek-előrevállalási hajlandóság a jövőben születendő gyermekkel a kétcsaládossá válók (58 százalék) körében jelentkezik, az előre vállalók 38 százaléka pedig három gyermeket kíván nevelni (KINCS 2019). Az igénylők 14,9 százaléka csak a támogatás ösztönző hatására vállalt további gyermeket (KINCS 2020a). Az ingatlan típusát 
tekintve a használt ingatlanszerzés dominál mind az előre vállalók (69,2 százalék), mind a támogatást csak meglévő gyermek után igénylők (68 százalék) esetében, a használt ingatlanokhoz kapcsolódó nagyobb gyermek-előrevállalási hajlandóság mellett (KINCS 2019).

A Központi Statisztikai Hivatal (KSH) adatbázisa alapján a támogatás gyermekek számára gyakorolt kedvező hatása 2016-2019 között még nem mutatkozott meg. Ugyan 2020-ban 3,3 százalékkal több gyermek született az előző évhez viszonyítva, de a 2016-os értéket még így sem sikerült elérni (KSH 2021b).

A támogatás gyermekek számára gyakorolt kedvező hatásával kapcsolatban több tanulmány is született. Ezek alapján a CSOK-támogatás a jövőben még javíthatja a gyermekvállalási hajlandóságot, de a családpolitika sikeressége ezen a téren erősen függ az életszínvonalbeli és egyéb, erkölcsi-etikai normáktól (Sági - Lentner 2020; Tatay et al. 2019).

A folyósított támogatás átlagos értéke 2,4 millió forint (újingatlan-vásárlás 5,2, használtingatlan-szerzés 2,4 millió forint). A támogatott összeg 78 százaléka kapcsolódik új ingatlanokhoz, 2 százalék bővítéshez. 2016-2019 közt minden 6. ingatlanszerzés (új ingatlanok 44 százalékához, használtak 12 százalékához) CSOK igénybevételével történt (KSH 2021a; KINCS 2019).

A Magyar Nemzeti Bank (MNB) 2020 novemberi lakáspiaci jelentése alapján a támogatott hitelfelvételek terén folyamatos emelkedés figyelhető meg, ám 2020 II. félévétől kezdődően visszaesés tapasztalható az új és a használt ingatlanok finanszírozása esetében is, aminek hátterében valószínúleg a pandémia okozta bizonytalanság áll. A vissza nem térítendő támogatást az igénylők 77 százaléka hitel felvételével is kiegészíti. A CSOK-támogatott hitelt 2020 első félévéig 134 ezren igényelték, 400 milliárd forint értékben (MNB 2020).

A CSOK megjelenése a megnövekvő kereslet révén jelentősen felhajtotta az ingatlanok árát, ami felemésztette a támogatási összeg közel 75 százalékát (Banai et al. 2019), ezzel tovább nehezítve a fiatal párok lakásszerzési lehetőségeit (Elek - Szikra 2018).

Sági és szerzőtársai (2017) kutatásuk alapján a támogatás társadalmi megítélése pozitiv, ugyanis a megkérdezettek több mint 60 százaléka véli úgy, hogy a támogatás segítségére lesz a lakásvásárlásban. Ezt erősíti meg a KINCS (2020a, b), és Tóth Horváthné (2018) kutatása is. Az egyes családpolitikai intézkedések ugyan javíthatják a fiatalok gyermekvállalási hajlandóságát, de az életszínvonalbeli adottságok, a stabil gazdasági, munkahelyi, és párkapcsolati háttér, az infláció, munkanélküliség, jövedelmi tényezők, egészség, vallás, etnikumbeli hovatartozás, erkölcsi normák és a kommunista múlt sokkal fajsúlyosabb tényezőnek bizonyul, mint a lakhatási körülmények. Ez különösen a gyermekvállalásban erősen bizonytalan párokra igaz. Ezen 
tényezők pedig kevéssé befolyásolhatók célzott szakpolitikai döntésekkel (Kapitány - Spéder 2018; Spéder et al. 2017; Sági - Lentner 2020; Szikra 2016; KSH 2016).

\subsection{A CSOK vissza nem térítendő támogatást igénybe vevők vizsgálata}

A régiók közül Nyugat-Dunántúlon a legmagasabb a nettó 1 főre eső jövedelem, a legalacsonyabb a munkanélküliség, és a regionális szinten meghatározott 1 főre jutó GDP tekintetében a vizsgált 3 régió adja a teljes megtermelt GDP 44 százalékát (KSH 2018a, 2020a, 2020b). Az igénylések száma, a 2020-as év kivételével (1. ábra) folyamatos emelkedést mutat. A visszaesés a vírushelyzet miatt kialakult bizonytalanságra vezethető vissza. Ez a jelenség nemcsak ezekben a régiókban, hanem országosan is megfigyelhető. Nyugaton a hatás kicsit erősebbnek mutatkozik, hiszen Ausztria részlegesen korlátozta a külföldiek munkavégzését.

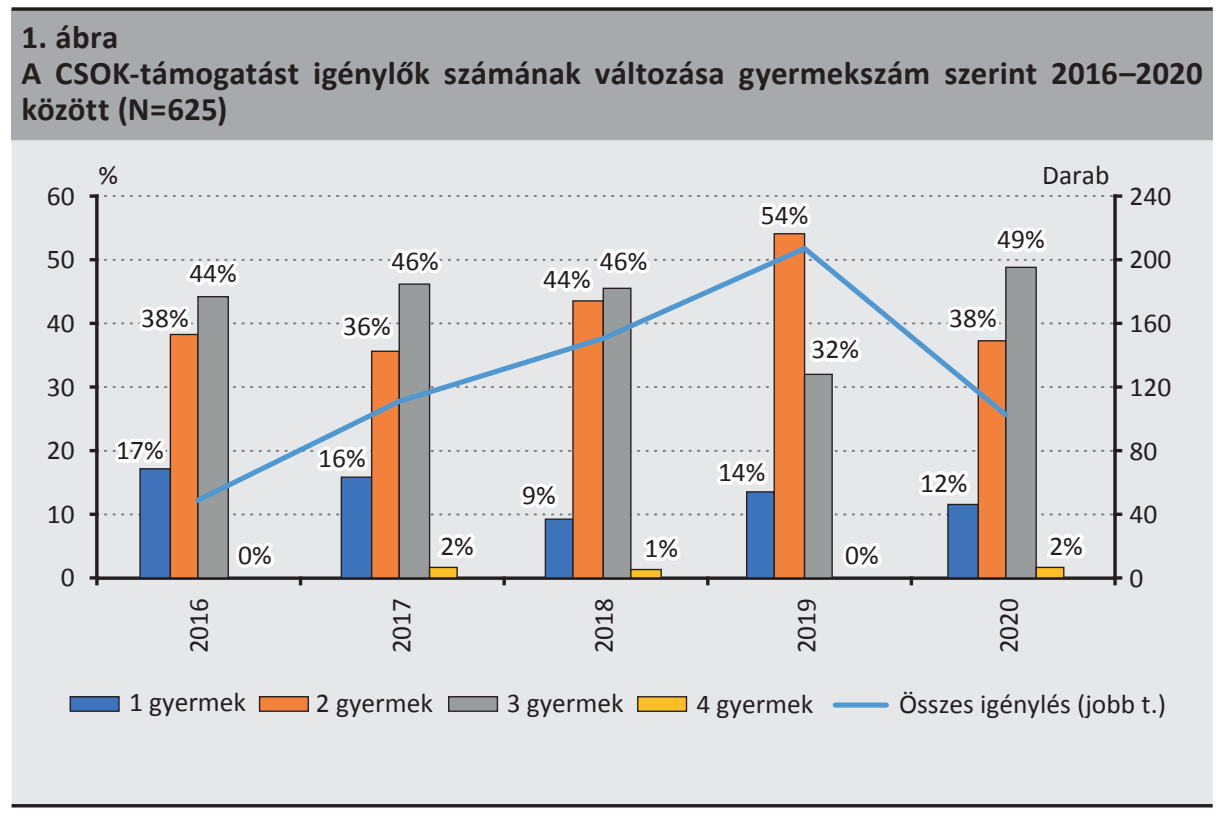

A legnagyobb érdeklődés 2019-ben jelentkezett, aminek hátterében a kétgyermekes családoknak megítélt kamattámogatott hitel igénybevételének lehetősége áll. Ez is mutatja, hogy a fizetendő kamat csökkenésének kedvező hatása van az ingatlanpiacra. Az állami kamattámogatás okozta torzító hatások következtében a hiteladós kisebb mértékben van kitéve az esetleges negatív konjunktúrafolyamatok által gerjesztett növekvő kamatszolgálatnak (Kiss - Vadas 2006). Az összes igénylőből 234 család (37 százalék) kizárólag a vissza nem térítendő támogatást vette igénybe. A támogatást igénylők 63 százaléka az állami támogatást hitel felvételével egészítette ki. 
A gyermekek számát tekintve elmondható, hogy az igénylések 44 százaléka kétgyermekes családmodellben (meglévő és előre vállalt gyermekekkel együtt) történt (4. táblázat). Három gyermeket a családok 43 százaléka kíván nevelni. Az egygyermekes családok száma mindössze 13 százalék.

\section{4. táblázat}

A 2016-2020 között támogatást igénylők megoszlása gyermekszám és az előre vállalt gyermekek száma szerint

\begin{tabular}{|c|c|c|c|c|c|c|c|c|c|c|c|}
\hline & \multicolumn{2}{|c|}{$\begin{array}{l}\text { Egygyermekes } \\
\text { családmodell }\end{array}$} & \multicolumn{4}{|c|}{$\begin{array}{l}\text { Kétgyermekes } \\
\text { családmodell }\end{array}$} & \multicolumn{5}{|c|}{$\begin{array}{l}\text { Háromgyermekes } \\
\text { családmodell }\end{array}$} \\
\hline & \multicolumn{11}{|c|}{ gyermek } \\
\hline & összes & meglévő & összes & meglévő & $\begin{array}{l}1 \text { elöre } \\
\text { vállalt }\end{array}$ & $\begin{array}{l}2 \text { elöre } \\
\text { vállalt }\end{array}$ & összes & meglévő & $\begin{array}{l}1 \text { elöre } \\
\text { vállalt }\end{array}$ & $\begin{array}{l}2 \text { elöre } \\
\text { vállalt }\end{array}$ & $\begin{array}{l}3 \text { elöre } \\
\text { vállalt }\end{array}$ \\
\hline Támogatást igénylő (db) & 81 & 81 & 277 & 178 & 51 & 48 & 267 & 221 & 26 & 17 & 3 \\
\hline Hitelt nem vesz igénybe ( $d b)$ & 74 & 74 & 114 & 109 & 5 & 0 & 46 & 40 & 3 & 2 & 1 \\
\hline $\begin{array}{l}\text { Támogatott és/ vagy piaci } \\
\text { hitelt is igénybe vesz (db) }\end{array}$ & 7 & 7 & 163 & 69 & 46 & 48 & 221 & 181 & 23 & 15 & 2 \\
\hline
\end{tabular}

Azok, akik csak a támogatást vették igénybe 32 százalékban egy gyermek után, 49 százalékban két gyermekre és mindössze 19 százalékban három gyermekre tették ezt meg. A hitelt is felvevők esetében minimális 2 százalék az egygyermekes családok száma. Ennek hátterében az alacsony támogatási összeg és a kamattámogatott hitel hiánya áll (Horváthné Kökény - Tóth 2017). Körükben a legmeghatározóbb a nagycsaládosok részaránya (57 százalék), melyben szerepet játszik a program teljes időtartama alatt elérhető kamattámogatott hitel is. Országosan a családok 36 százaléka egy, 22 százaléka kettő, 6 százaléka három-, és 2 százaléka négy vagy több gyermeket nevel. A CSOK-támogatottak körében az országos mintához képest többszörösen nagyobb részarányt képviselnek a kétgyermekesek, és a háromgyermekesek még ennél is nagyobbat (KSH 2012a). Az országos KSH-adatok alapján a lakáscélú jelzáloghitelt felvevők között a legnagyobb százalékban a gyermektelenek (32 százalék) és a kétgyermekesek (30 százalék) fordulnak elő. Őket követik az egygyermekes családok (26 százalék). A nagycsaládosok képviseltetik magukat a legkisebb százalékban (12 százalék) a hitelfelvevők között (KSH 2018b), ami pont az ellenkezője a CSOK-program igénybe vevői körében tapasztalt gyermekszám szerinti megoszlásnak.

A programmal a kormány demográfiai célok megvalósulását, a születések számának növekedését is elő kívánja segíteni. Az igénylők ehhez a tervezett gyermekeiken túli gyermekek születésével tudnak leginkább hozzájárulni. Az állami támogatásból részesülők mindössze 23 százaléka vállal előre gyermeket (4. táblázat), ami elmarad az országos szintű 33 százalékos gyermek-előrevállalási hajlandóságtól (KINCS 2019). Az előre vállalók 68 százaléka két gyermeket, míg 32 százalékuk három gyermeket kíván nevelni a jövőben. Az igénylők 77 százaléka már megszületett gyermeke után 
igényli a támogatást. Az előre vállalóktól abban az esetben várhatjuk a népességnövekedés elősegítését, ha ők korábban nem tervezett gyermek születése mellett kötelezték el magukat a támogatás hatására, és nem csak a későbbre tervezett gyermekvállalásukat hozták korábbi időpontra. Azon igénylők körében a legnagyobb a gyermek- előrevállalási hajlandóság (36 százalék), akik maximum két gyermeket kívánnak nevelni (az előre vállalt gyermeket is figyelembe véve). A három gyermek iránt elkötelezett családok 17 százaléka tesz ígéretet arra, hogy a törvényi határidőn belül gyermekei száma 3-ra növekszik. 2020 végéig az összes előre vállaló 62 százaléka teljesítette vállalását, azaz világra hozta a vállalt gyermekét. Mindössze egy olyan igénylő volt, aki 2016-ban vette igénybe a támogatást és nem született meg a jogszabályban rögzítetett határidőig a vállalt gyermek. Ha a fiatal házaspár a gyermekvállalást nem, vagy csak részben teljesíti (kivéve az igazolt egészségügyi ok esetét), úgy az igénybe vett kedvezmény összegét késedelmi kamattal, három vagy több gyermek vállalása esetén a büntetőkamat ötszörösével növelten vissza kell fizetni az államnak. Ezzel kívánja a kormány elejét venni a megalapozatlan gyermek-előrevállalásoknak, melyek csak a magasabb támogatási összegek lehívására irányulnának.

Az összes jövőbeni gyermekvállalás mellett elkötelezett igénylő 45 százaléka további két gyermek (12 százalék a 2. és a 3. gyermekét tervezi, ami az összes támogatást igénylő 2 százaléka), 2 százalék pedig 3 gyermek megszületését vállalja (5. táblázat). A többi előrevállaló további egy gyermeket tervez.

\begin{tabular}{|c|c|c|}
\hline \multicolumn{3}{|l|}{$\begin{array}{l}\text { 5. táblázat } \\
\text { A kétgyermeke } \\
\text { gyermeket válla }\end{array}$} \\
\hline & & $\begin{array}{l}\text { Gyermek-elörevállalási hajlandóság } \\
\qquad(\mathrm{N}=135)\end{array}$ \\
\hline \multirow{2}{*}{$\begin{array}{l}2 \text { gyermekes } \\
\text { családmodell }\end{array}$} & $\begin{array}{l}1 \text { gyermeket } \\
\text { (2. gyermeket) vállal elöre }\end{array}$ & $35 \%$ \\
\hline & \begin{tabular}{|l}
2 gyermeket \\
$(1 .+2$. gyermeket) vállal előre
\end{tabular} & $33 \%$ \\
\hline \multirow{3}{*}{ Nagycsaládos } & $\begin{array}{l}1 \text { gyermeket } \\
\text { (3. gyermeket) vállal előre }\end{array}$ & $18 \%$ \\
\hline & $\begin{array}{l}2 \text { gyermeket } \\
(2 .+3 \text {. gyermeket) vállal előre }\end{array}$ & $12 \%$ \\
\hline & $\begin{array}{l}3 \text { gyermeket } \\
(1 .+2 .+3 . \text { gyermeket) vállal előre }\end{array}$ & $2 \%$ \\
\hline \multicolumn{3}{|l|}{ Összes előre vállaló } \\
\hline \multirow{3}{*}{ Összes előre vállaló } & 1 gyermeket előre vállalók & $53 \%$ \\
\hline & 2 gyermeket elóre vállalók & $45 \%$ \\
\hline & 3 gyermeket előre vállalók & $2 \%$ \\
\hline
\end{tabular}


A támogatási feltételek terén a 2019-es év kedvező változásokat hozott, ami az igénylések számában, a támogatást hitellel kiegészítők arányának növekedésében (6. táblázat) is megmutatkozik.

\begin{tabular}{|c|c|c|c|c|c|}
\hline \multicolumn{6}{|c|}{ A CSOK-támogatás igénybevétele családméret és az igénylés éve szerint } \\
\hline & \multicolumn{2}{|c|}{ Nagycsalád } & \multicolumn{2}{|c|}{ Nem nagycsalád } & \multirow{2}{*}{$\begin{array}{l}\text { Összesen } \\
\text { (db) }\end{array}$} \\
\hline & nincs hitele & van hitele & nincs hitele & van hitele & \\
\hline $2016(d b)$ & 10 & 13 & 20 & 9 & 52 \\
\hline $\begin{array}{c}\text { Új } \\
\text { ingatlan }\end{array}$ & \multicolumn{2}{|c|}{$74 \%$} & \multicolumn{2}{|c|}{$45 \%$} & 30 \\
\hline $\begin{array}{l}\text { Használt } \\
\text { ingatlan }\end{array}$ & \multicolumn{2}{|c|}{$26 \%$} & \multicolumn{2}{|c|}{$55 \%$} & 22 \\
\hline 2017 (db) & 16 & 38 & 50 & 8 & 112 \\
\hline $\begin{array}{c}\text { Új } \\
\text { ingatlan }\end{array}$ & \multicolumn{2}{|c|}{$41 \%$} & \multicolumn{2}{|c|}{$76 \%$} & 66 \\
\hline $\begin{array}{l}\text { Használt } \\
\text { ingatlan }\end{array}$ & \multicolumn{2}{|c|}{$59 \%$} & \multicolumn{2}{|c|}{$24 \%$} & 46 \\
\hline $2018(d b)$ & 12 & 59 & 52 & 28 & 151 \\
\hline $\begin{array}{c}\text { Új } \\
\text { ingatlan }\end{array}$ & \multicolumn{2}{|c|}{$34 \%$} & \multicolumn{2}{|c|}{$38 \%$} & 54 \\
\hline $\begin{array}{l}\text { Használt } \\
\text { ingatlan }\end{array}$ & \multicolumn{2}{|c|}{$66 \%$} & \multicolumn{2}{|c|}{$63 \%$} & 97 \\
\hline $2019(\mathrm{db})$ & 2 & 64 & 44 & 96 & 206 \\
\hline $\begin{array}{c}\text { Új } \\
\text { ingatlan }\end{array}$ & \multicolumn{2}{|c|}{$33 \%$} & \multicolumn{2}{|c|}{$58 \%$} & 103 \\
\hline $\begin{array}{l}\text { Használt } \\
\text { ingatlan }\end{array}$ & \multicolumn{2}{|c|}{$67 \%$} & \multicolumn{2}{|c|}{$42 \%$} & 103 \\
\hline $2020(\mathrm{db})$ & 6 & 47 & 22 & 29 & 104 \\
\hline $\begin{array}{c}\text { Új } \\
\text { ingatlan }\end{array}$ & \multicolumn{2}{|c|}{$51 \%$} & \multicolumn{2}{|c|}{$41 \%$} & 48 \\
\hline $\begin{array}{l}\text { Használt } \\
\text { ingatlan }\end{array}$ & \multicolumn{2}{|c|}{$49 \%$} & \multicolumn{2}{|c|}{$59 \%$} & 56 \\
\hline Összesen (db) & 46 & 221 & 188 & 170 & 625 \\
\hline
\end{tabular}

Az évek során mindkét családmodell esetében nőtt a használt ingatlanok részaránya. 2019-ben a nagycsaládosok körében további növekedés, míg a kétgyermekes családmodell elkötelezettjeinél kisebb visszaesés figyelhető meg a használt ingatlanok iránt. Úgy véljük, hogy ezen irányú változásokat az okozza, hogy a kamattámogatott hitel a 2019. év elejétől a kétgyermekesek számára is igényelhető új ingatlanokhoz, az év közepétől pedig már használt ingatlan szerzésére is, ami a nagycsaládosokat is inspirálta. Összességében a nagycsaládosok 58 százaléka, a nem nagycsaládosoknak pedig 47 százaléka vásárolt használt ingatlant a támogatás felhasználásával. 
A használt ingatlanokra vonatkozó 35 millió forintos maximális ingatlanár korlátjának eltörlését követően a határértéket meghaladó ingatlanok 40 százaléka használt ingatlan. Összességében azonban nem történt több nagy értékű ingatlanvásárlás, sőt a 35 millió forint feletti használt és új ingatlanok állománya csökkenő tendenciát mutat a 2019 előtti és az azt követő időszak viszonyában.

Szintén a használt ingatlanok esetében történt változás 2018-ban, amikor eltörölték, hogy a már meglévő ingatlannal rendelkezők nem vehetnek igénybe CSOK-támogatást használt ingatlan szerzésére meglévő ingatlanjuk megtartása mellett. A meglévő ingatlan mellett támogatást igénylők több mint 90 százaléka használt ingatlanra vette igénybe a CSOK közvetlen támogatást, 2019-ben 61 százalékra csökkent az arányuk. A gyermek-előrevállalási hajlandóságot is figyelembe véve megállapítható, hogy az előre vállalók mindössze 2 százaléka vásárolt korábbi ingatlana mellé másikat a támogatás igénybevételével.

A preferált kistérségekben történő ingatlanvásárlás a mintában 5 százalék alatti, ezért ezen területek támogatásának hatását nem érezzük a mintaelemszámok növekedésében. Ennek hátterében meghúzódhat, hogy a vizsgált régiók tekintetében alacsony a támogatott kistérségek száma, fejlettségi szintjük viszont az országos átlagot meghaladó.

A közvetlen támogatást igénylők 48 százaléka új (összesen 1,5 milliárd Ft, átlagosan 5 millió Ft/ ingatlan), 45 százaléka használt ingatlan vásárlását (összesen 485 millió Ft, átlagosan 1,7 millió Ft/ ingatlan) és 7 százaléka bővítési (összesen 67 millió Ft, átlagosan 1,5 millió Ft/ ingatlan) munkálatokat finanszíroz a kapott összegből (2. ábra). A gyermekenkénti megoszlás új ingatlanvásárlás esetén rendre 15 százalék (összesen 26 millió Ft, 0,6 millió Ft/ ingatlan), 48 százalék (összesen 377 millió Ft, 2,6 millió Ft/ ingatlan), 37 százalék (összesen 1 milliárd Ft, 10 millió Ft/ ingatlan). Használt ingatlan szerzése esetén pedig rendre 13-35-52 százalék. Az új ingatlanberuházások után kerül kifizetésre a támogatás háromnegyede. A kifizetett támogatási összeg fele a jogosultak 18 százalékánál (gyermeket előre vállalók nélkül 14 százalék) összpontosul, azon okból kifolyólag, hogy ők nagycsaládosok, így az új ingatlan szerzéséhez 10 millió forint vissza nem térítendő állami támogatásban részesülnek. Az összes igénylő 23 százalékát adó kétgyermekes új ingatlant vásárló családok a kifizetések kevesebb mint 20 százalékában részesülnek, annak ellenére, hogy ők nagyobb számban hajtottak végre új ingatlan szerzésére irányuló tranzakciót. Ennek oka, hogy esetükben az állam 2,6 millió forint támogatással segíti az adásvételt. 


\section{2. ábra \\ A CSOK közvetlen támogatást igénylők száma és részesedésük a lehívott támogatási összegből gyermekszám és ingatlantípus szerint ( $\mathrm{N}=625)$}

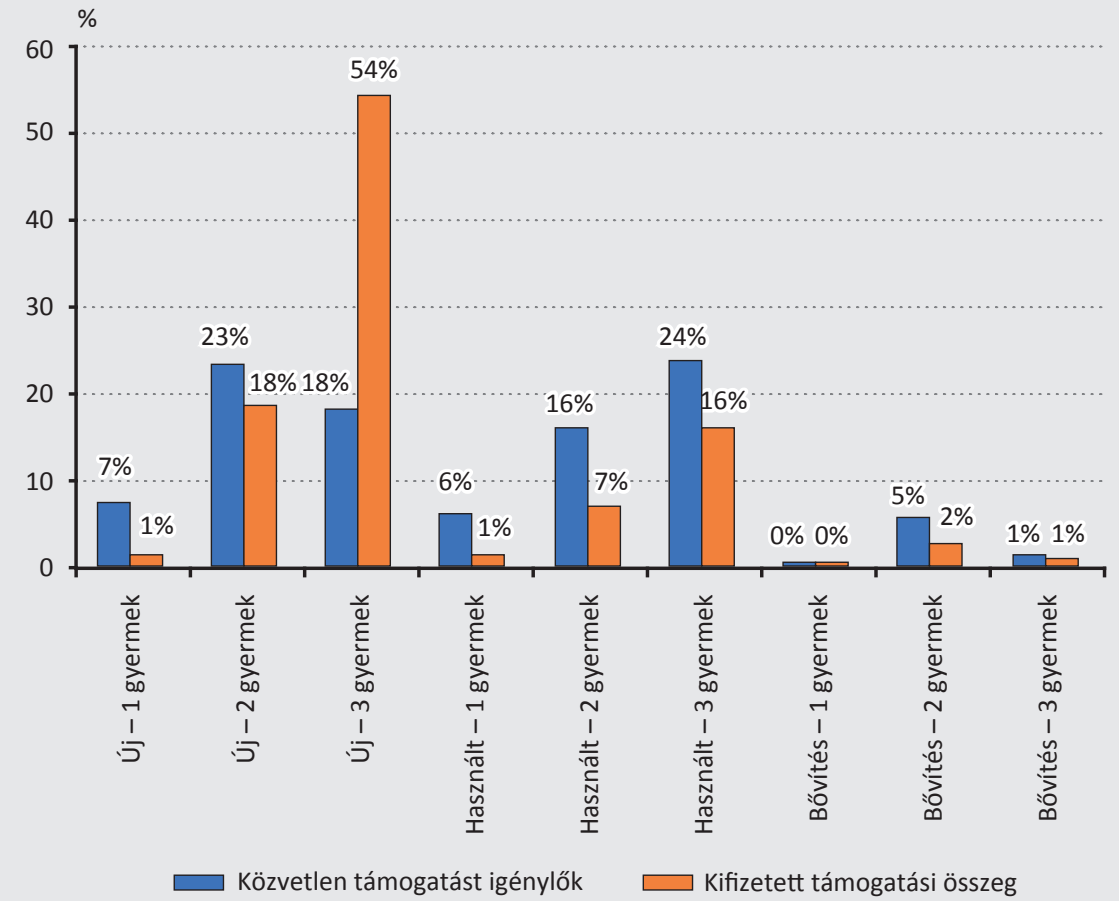

A gyermeket előre vállalók a támogatás 24 százalékát (495 millió Ft) kapják meg. Közülük 55 százalék új-, 39 százalékuk használt ingatlant vásárol, 6 százalékuk pedig bővít. Az előre vállaló 2 gyerekesek (az előre vállalt gyermeket is beleértve) 57 százaléka, a három gyermekesek (előre vállalt gyermekkel együtt) 52 százaléka új ingatlan vételét valósítja meg a támogatásból. A két családmodell megoszlása közel azonos az új ingatlanba beruházó, gyermeket előre vállalók között. A kifizetett támogatási összeg azonban a nagycsaládosok javára jelentős eltérést mutat. A gyermekvállalással nagycsaládossá válók által realizált támogatási összeg az összes előre vállaló számára kifizetett összeg 48 százaléka, a kétgyermekesek esetében ez 30 százalék. Az új ingatlanok után járó magas 10 millió forintos támogatási összeg ösztönző hatására sem növekedett a gyermekvállalással kétgyermekes családdá válók számát meghaladó mértékben a háromgyermekes családdá válók száma. A nagycsaládos igénylők 14 százaléka a támogatást új ingatlan vásárlására fordítja és már az igényléskor három gyermeke van. 


\subsection{Az igénylők jövedelem és ingatlanár szerinti csoportosítása a családméret függvényében}

Jövedelmi adatok 391 háztartás esetében álltak rendelkezésre. A kiugró értékek eltávolítása után 371 családot vizsgáltunk tovább. A hitelt felvevők közt nagyobb arányban (57 százalék) fordulnak elő nagycsaládosok. A támogatással a nem nagycsaládosok 72 százaléka 35 millió forintos ingatlanérték alatt valósítja meg otthonteremtési vágyait (3. ábra). Ötvenmillió forintot meghaladó értékű ingatlant a kétgyermekesek 11 százaléka, a nagycsaládosok 5 százaléka vásárol (előre vállalt gyermekkel együtt).

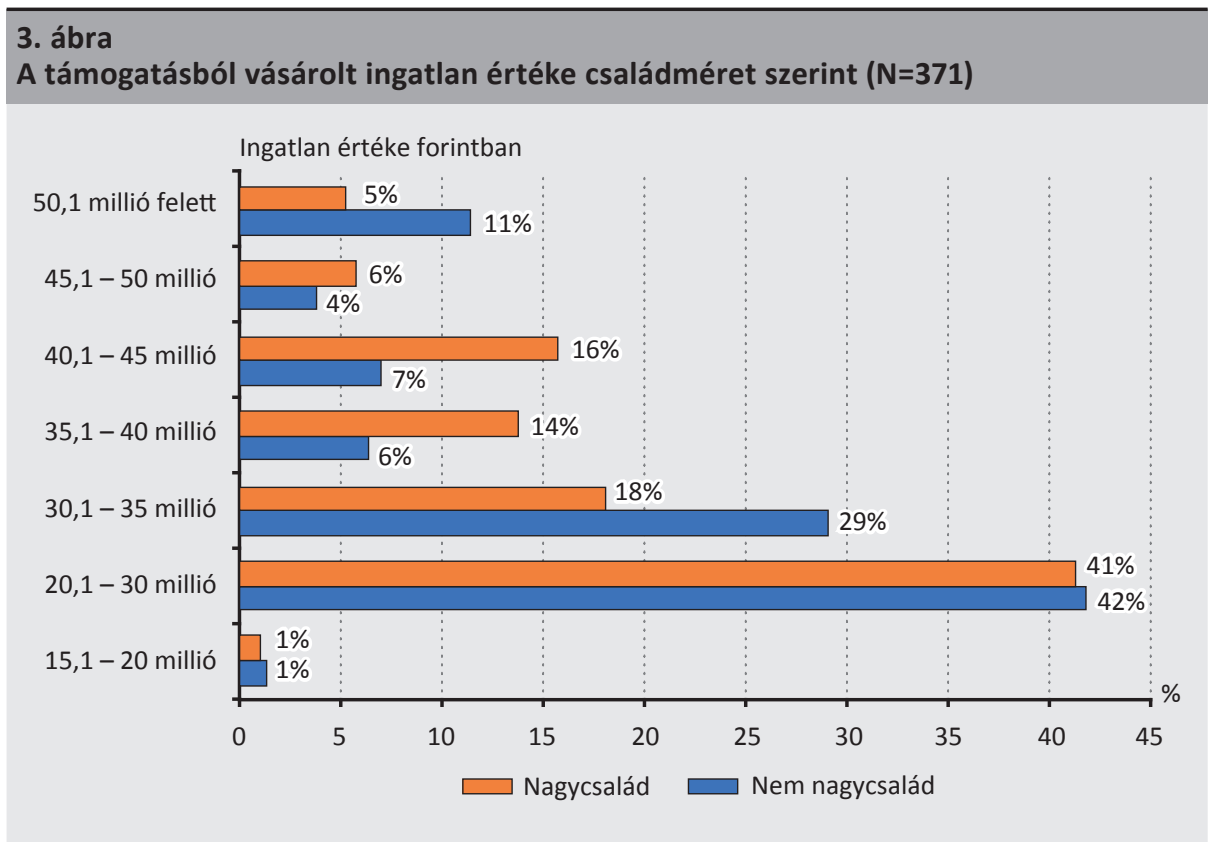

A nem nagycsaládosok jórészt kisebb alapterületű új ingatlanokat vásárolnak (7. táblázat). Ugyanez a nagycsaládosok körében 60 százalék, akik kicsit nagyobb méretü - a nagyobb családméret okán is - és inkább használt ingatlanokat vesznek. 


\begin{tabular}{|c|c|c|c|c|c|c|}
\hline \multicolumn{7}{|c|}{$\begin{array}{l}\text { 7. táblázat } \\
\text { Ingatlanberuházások családméret, ingatlantípus és hasznos ingatlan-alapterület szerinti } \\
\text { megoszlása }\end{array}$} \\
\hline \multirow[b]{2}{*}{$\begin{array}{l}\text { Ingatlan } \\
\text { alapterülete }\end{array}$} & \multicolumn{3}{|c|}{ Nem nagycsalád } & \multicolumn{3}{|c|}{ Nagycsalád } \\
\hline & $\begin{array}{c}\text { Új } \\
\text { ingatlan }\end{array}$ & $\begin{array}{l}\text { Használt } \\
\text { ingatlan }\end{array}$ & $\begin{array}{c}\text { A nem } \\
\text { nagycsaládosok } \\
\text { tulajdonában lévő } \\
\text { ingatlanok } \\
\text { megoszlása } \\
\text { alapterület szerint }\end{array}$ & $\begin{array}{c}\text { Új } \\
\text { ingatlan }\end{array}$ & $\begin{array}{l}\text { Használt } \\
\text { ingatlan }\end{array}$ & $\begin{array}{l}\text { A nagycsaládosok } \\
\text { tulajdonában lévő } \\
\text { ingatlanok } \\
\text { megoszlása } \\
\text { alapterület szerint }\end{array}$ \\
\hline $60 \mathrm{~m}^{2}$ alatt & $16 \%$ & $4 \%$ & $10 \%$ & $3 \%$ & $5 \%$ & $4 \%$ \\
\hline $61-70 \mathrm{~m}^{2}$ & $5 \%$ & $4 \%$ & $4 \%$ & $12 \%$ & $4 \%$ & $7 \%$ \\
\hline $71-80 \mathrm{~m}^{2}$ & $15 \%$ & $30 \%$ & $22 \%$ & $24 \%$ & $15 \%$ & $18 \%$ \\
\hline $81-90 \mathrm{~m}^{2}$ & $11 \%$ & $23 \%$ & $17 \%$ & $14 \%$ & $16 \%$ & $15 \%$ \\
\hline $91-100 \mathrm{~m}^{2}$ & $15 \%$ & $12 \%$ & $13 \%$ & $35 \%$ & $15 \%$ & $22 \%$ \\
\hline $101-110 \mathrm{~m}^{2}$ & $4 \%$ & $9 \%$ & $6 \%$ & $4 \%$ & $7 \%$ & $6 \%$ \\
\hline $111-120 \mathrm{~m}^{2}$ & $5 \%$ & $4 \%$ & $4 \%$ & $0 \%$ & $8 \%$ & $5 \%$ \\
\hline $121-140 \mathrm{~m}^{2}$ & $4 \%$ & $3 \%$ & $3 \%$ & $3 \%$ & $9 \%$ & $7 \%$ \\
\hline $141 \mathrm{~m}^{2}$ felett & $27 \%$ & $12 \%$ & $19 \%$ & $6 \%$ & $21 \%$ & $16 \%$ \\
\hline \multicolumn{7}{|c|}{ Összes új és használt ingatlanba történő beruházás az adott családméret viszonyában } \\
\hline $\begin{array}{c}\text { Ingatlan } \\
\text { beruházások }\end{array}$ & $52 \%$ & $48 \%$ & & $37 \%$ & $63 \%$ & \\
\hline
\end{tabular}

Országos viszonylatban a magánszemélyek tulajdonában lévő ingatlanok 32 százaléka $60 \mathrm{~m}^{2}$ alatti alapterülettel rendelkezik. A CSOK-ot igénylők közt a törvényi előírás miatt nem lehet az ingatlan $60 \mathrm{~m}^{2}$ alatti. A teljes magyar népesség 43 százaléka 60-100 m² közötti ingatlanban él. Az e feletti ingatlanok aránya közel 35 százalék a CSOK-igénylők körében, országosan pedig 25 százalék. Az adatokból látható, hogy a CSOK-támogatás megemelte a megvásárolt ingatlan alapterületét (KSH 2012b).

A családi jövedelmet 5 egyenlő elemszámú jövedelmi csoportra osztva megállapítható, hogy a hitellel rendelkezők körében a nagycsaládosok részaránya (57 százalék) nagyobb a nem nagycsaládosokénál. Ez annak köszönhető, hogy a 3. és az e feletti jövedelmi sávokban az arányuk meghaladja (a legnagyobb mértékben a 4. jövedelmi sávban) a nem nagycsaládosokét (8. táblázat). 


\section{8. táblázat}

A CSOK-támogatás mellé hitelt is felvevők jövedelmi kategória, családméret és gyermek-előrevállalási hajlandóság szerinti megoszlása

\begin{tabular}{|c|c|c|c|c|c|c|}
\hline \multirow[b]{2}{*}{$\begin{array}{c}\text { Családi jövedelmi } \\
\text { sáv }\end{array}$} & \multicolumn{3}{|c|}{ Nem nagycsaládos } & \multicolumn{3}{|c|}{ Nagycsaládos } \\
\hline & $\begin{array}{c}\text { Nem } \\
\text { nagycsaládos } \\
\text { igénylök az } \\
\text { összes igénylő } \\
\text { arányában }\end{array}$ & $\begin{array}{l}\text { Gyermeket } \\
\text { előre vállalók } \\
\text { a nem } \\
\text { nagycsaládos } \\
\text { igénylők } \\
\text { arányában }\end{array}$ & $\begin{array}{l}\text { Gyermeket } \\
\text { előre vállalók } \\
\text { az elöre } \\
\text { vállalók } \\
\text { arányában }\end{array}$ & $\begin{array}{l}\text { Nagycsaládos } \\
\text { igénylők az } \\
\text { összes igénylő } \\
\text { arányában }\end{array}$ & $\begin{array}{c}\text { Gyermeket } \\
\text { előre vállalók } \\
\text { a nagycsaládos } \\
\text { igénylők } \\
\text { arányában }\end{array}$ & $\begin{array}{l}\text { Gyermeket } \\
\text { előre vállalók } \\
\text { az előre } \\
\text { vállalók } \\
\text { arányában }\end{array}$ \\
\hline $\begin{array}{l}\text { 1. sáv: } \\
0-418 \text { ezer forint }\end{array}$ & $53 \%$ & $64 \%$ & $81 \%$ & $47 \%$ & $17 \%$ & $19 \%$ \\
\hline $\begin{array}{l}\text { 2. sáv: } \\
\text { 419-487 ezer forint }\end{array}$ & $53 \%$ & $63 \%$ & $83 \%$ & $47 \%$ & $14 \%$ & $17 \%$ \\
\hline $\begin{array}{l}\text { 3. sáv: } \\
\text { 488-607 ezer forint }\end{array}$ & $39 \%$ & $68 \%$ & $61 \%$ & $61 \%$ & $27 \%$ & $39 \%$ \\
\hline $\begin{array}{l}\text { 4. sáv: } \\
608-760 \text { ezer forint }\end{array}$ & $27 \%$ & $50 \%$ & $50 \%$ & $73 \%$ & $19 \%$ & $50 \%$ \\
\hline $\begin{array}{l}\text { 5. sáv: } \\
761 \text { ezer forint felett }\end{array}$ & $43 \%$ & $38 \%$ & $67 \%$ & $57 \%$ & $14 \%$ & $33 \%$ \\
\hline $\begin{array}{l}\text { Összes hitellel } \\
\text { rendelkező igénylő }\end{array}$ & $43 \%$ & $57 \%$ & $70 \%$ & $57 \%$ & $18 \%$ & $30 \%$ \\
\hline
\end{tabular}

A kétgyermekes családmodell elkötelezettjei szerényebb családi jövedelem mellett vágnak bele az otthonteremtésbe. Ennek egyik oka a nagycsaládosok családi adókedvezménye által elérhető magasabb nettó jövedelem, valamint a családi jövedelembe szintén beleszámító családipótlék, gyermekgondozási - és csecsemőgondozási díj. A három gyermekes családok 82 százaléka már az igényléskor rendelkezett három gyermekkel. Ugyanez a kétgyermekes családok 43 százalékára igaz. A gyermeket előre vállalók jellemzően az alsóbb jövedelmi csoportokban találhatók, 62 százalékuk alacsonyabb értékű, 35 millió forintos és $80 \mathrm{~m}^{2}$ alatti hasznos alapterületű ingatlant vásárol. Ebből arra következtetünk, hogy számukra a támogatás teremtette meg a saját otthon megszerzésének lehetőségét.

A kormány a háromgyermekes családok újingatlan-vásárlását kiemelt mértékben támogatja. Azonban a nyugati régióban vizsgált háztartások esetében a két gyermekkel rendelkezők vagy a további gyermek vállalása révén azzá válók túlsúlya és az új ingatlan szerzése a jellemző. A nagycsaládosok (előre vállalt gyermekkel együtt) várakozásainkkal ellentétesen inkább használt ingatlant vásárolnak. Kisebb részük vállalt további gyermeket annak érdekében, hogy nagycsaládosok legyenek, és alacsony az egy meglévő gyermekhez további két gyermeket vállalók száma. 
Az igénylők 78 százaléka saját bevallása szerint a támogatás igénybevételekor nem rendelkezett lakóingatlannal. 14 százalékuk igen, de azt értékesítették annak érdekében, hogy a támogatás igénybevételével jobb lakhatási körülményeket teremthessenek a családnak (9. táblázat).

Az igénylők mindössze 8 százaléka (ebből 77 százalék nagycsaládos) tartotta meg korábbi otthonát, és vásárolt hozzá egy másikat a támogatás felhasználásával. Ezek a családok a felső 3 jövedelmi kategóriába tartoznak. Erre csak kevesen tudták felvenni a 10 millió forintos közvetlen támogatást, mert az ingatlantranzakciók mindössze 24 százaléka irányult új ingatlanra, amiből nem mindegyik vásárló volt nagycsaládos.

\section{9. táblázat}

Az igénylők családméret és jövedelmi sáv szerinti megoszlása annak függvényében, hogy a támogatással meglévő ingatlanjuk mellett történik-e az ingatlantranzakció

\begin{tabular}{|c|c|c|c|c|c|c|}
\hline \multirow[b]{2}{*}{$\begin{array}{c}\text { Családi } \\
\text { jövedelmi sáv }\end{array}$} & \multicolumn{3}{|c|}{$\begin{array}{l}\text { Nincs korábbi ingatlan, } \\
\text { vagy eladja és beforgatja }\end{array}$} & \multicolumn{3}{|c|}{ A korábbi ingatlant megtartja } \\
\hline & $\begin{array}{c}\text { Nem } \\
\text { nagycsaládos }\end{array}$ & Nagycsaládos & $\begin{array}{c}\text { A korábbi } \\
\text { ingatlannal } \\
\text { nem } \\
\text { rendelkezők } \\
\text { megoszlása az } \\
\text { összes igénylő } \\
\text { arányában }\end{array}$ & $\begin{array}{c}\text { Nem } \\
\text { nagycsaládos }\end{array}$ & Nagycsaládos & $\begin{array}{l}\text { A korábbi } \\
\text { ingatlant } \\
\text { megtartók } \\
\text { megoszlása az } \\
\text { összes igénylő } \\
\text { arányában }\end{array}$ \\
\hline $\begin{array}{l}\text { 1. sáv: } \\
0-418 \text { ezer forint }\end{array}$ & $53 \%$ & $47 \%$ & $100 \%$ & $0 \%$ & $0 \%$ & $0 \%$ \\
\hline $\begin{array}{l}\text { 2. sáv: } \\
419-487 \text { ezer forint }\end{array}$ & $53 \%$ & $47 \%$ & $100 \%$ & $0 \%$ & $0 \%$ & $0 \%$ \\
\hline $\begin{array}{l}\text { 3. sáv: } \\
\text { 488-607 ezer forint }\end{array}$ & $39 \%$ & $61 \%$ & $99 \%$ & $0 \%$ & $100 \%$ & $1 \%$ \\
\hline $\begin{array}{l}\text { 4. sáv: } \\
608-760 \text { ezer forint }\end{array}$ & $27 \%$ & $73 \%$ & $84 \%$ & $25 \%$ & $75 \%$ & $16 \%$ \\
\hline $\begin{array}{l}\text { 5. sáv: } \\
761 \text { ezer forint felett }\end{array}$ & $48 \%$ & $52 \%$ & $77 \%$ & $24 \%$ & $76 \%$ & $23 \%$ \\
\hline $\begin{array}{l}\text { Összes hitellel } \\
\text { rendelkező igénylő }\end{array}$ & $45 \%$ & $55 \%$ & $92 \%$ & $23 \%$ & $77 \%$ & $8 \%$ \\
\hline
\end{tabular}

Annak függvényében, hogy az igénylők milyen családi jövedelemmel rendelkeznek és a támogatás felhasználásával milyen piaci értékú ingatlant tudtak megvásárolni, klaszteranalízissel 7 egymástól elkülönülő csoportot alakítottunk ki. A három legnagyobb csoport a vizsgált minta elemeinek 83 százalékát tömöríti. A varianciaértékek és a klaszterek közti távolság alapján is a hétklaszteres megoldás mutatja a legnagyobb csoporton belüli hasonlóságot. 
Vizsgálatunk során arra kerestük a választ, hogy a támogatás milyen társadalmi csoportok számára nyújt nélkülözhetetlen segítséget lakáscéljaik elérésére, és milyen jövedelmi színvonal és ingatlanérték esetén indukálja a második otthon megszerzését.

\section{4. ábra \\ A támogatást igénylők családi jövedelem és ingatlanár szerinti csoportosítása}

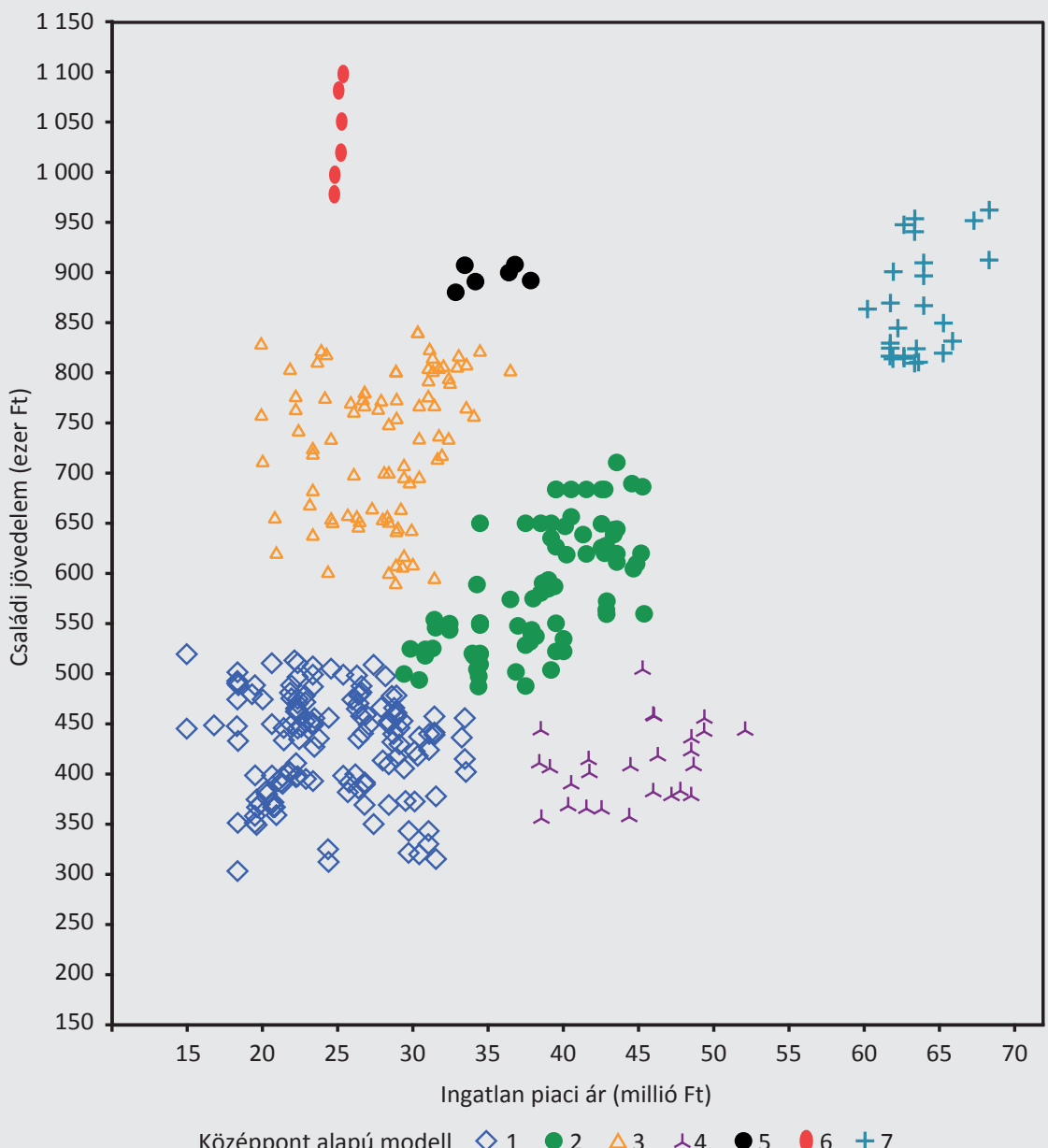


$A z$ 1. csoport a legnépesebb a maga 38 százalékos részesedésével (10. táblázat). Ezzel együtt ők mondhatják magukénak a legkisebb értékú, 26 millió forint átlagáras ingatlanokat (4. ábra) és a legszerényebb jövedelmeket (429 ezer forint), így a csoport az első ingatlanját vásárolja meg a támogatással. Itt a legmagasabb a kétgyermekes családok száma (52 százalék). A 4. csoporthoz hasonlóan esetükben is magas (42 százalék) a gyermek-előrevállalási hajlandóság, melyet részben az ingatlanszerzés indukálhatott, az alacsony jövedelmi szint miatt (10. táblázat).

\section{0. táblázat}

Az egyes csoportok részesedése, valamint családméret, gyermek-előrevállalás és meglévő ingatlan szerinti összetétele

\begin{tabular}{|c|c|c|c|c|c|}
\hline & $\begin{array}{c}\text { Csoport } \\
\text { tagjainak } \\
\text { a száma (db) }\end{array}$ & $\begin{array}{l}\text { Csoport } \\
\text { részesedése }\end{array}$ & $\begin{array}{l}\text { Családmodell } \\
\text { szerinti } \\
\text { megoszlás } \\
\text { a csoport } \\
\text { arányában }\end{array}$ & $\begin{array}{l}\text { Csoporton } \\
\text { belüli } \\
\text { gyermek- } \\
\text { előrevállalási } \\
\text { hajlandóság }\end{array}$ & $\begin{array}{c}\text { Korábbi } \\
\text { ingatlannal } \\
\text { rendelkezik és } \\
\text { megtartja (db) }\end{array}$ \\
\hline 1. csoport & 142 & \multirow{3}{*}{$38 \%$} & & $42 \%$ & 0 \\
\hline Nagycsalád & 68 & & $48 \%$ & $18 \%$ & 0 \\
\hline Nem nagycsalád & 74 & & $52 \%$ & $64 \%$ & 0 \\
\hline 2. csoport & 79 & \multirow{3}{*}{$21 \%$} & & $38 \%$ & 9 \\
\hline Nagycsalád & 56 & & $71 \%$ & $23 \%$ & 9 \\
\hline Nem nagycsalád & 23 & & $29 \%$ & $74 \%$ & 0 \\
\hline 3. csoport & 87 & \multirow{3}{*}{$23 \%$} & & $18 \%$ & 15 \\
\hline Nagycsalád & 57 & & $66 \%$ & $7 \%$ & 10 \\
\hline Nem nagycsalád & 30 & & $34 \%$ & $40 \%$ & 5 \\
\hline 4. csoport & 26 & \multirow{3}{*}{$7 \%$} & & $54 \%$ & 0 \\
\hline Nagycsalád & 14 & & $54 \%$ & $36 \%$ & 0 \\
\hline Nem nagycsalád & 12 & & $46 \%$ & $75 \%$ & 0 \\
\hline 5. csoport & 6 & \multirow{3}{*}{$2 \%$} & & $0 \%$ & 6 \\
\hline Nagycsalád & 4 & & $67 \%$ & $0 \%$ & 4 \\
\hline Nem nagycsalád & 2 & & $33 \%$ & $0 \%$ & 2 \\
\hline 6. csoport & 6 & \multirow{3}{*}{$2 \%$} & & $33 \%$ & 0 \\
\hline Nagycsalád & 3 & & $50 \%$ & $33 \%$ & 0 \\
\hline Nem nagycsalád & 3 & & $50 \%$ & $33 \%$ & 0 \\
\hline 7. csoport & 25 & \multirow{3}{*}{$7 \%$} & & $36 \%$ & 0 \\
\hline Nagycsalád & 10 & & $40 \%$ & $40 \%$ & 0 \\
\hline Nem nagycsalád & 15 & & $60 \%$ & $33 \%$ & 0 \\
\hline
\end{tabular}

Megállapíthatjuk, hogy a szerényebb jövedelemmel rendelkezők hajlamosabbak további gyermek vállalására elkötelezni magukat. A háztartások 70 százalékot meghaladóan használták fel a támogatást használt ingatlan megszerzéséhez (11. táblázat). Ez is hozzájárul, hogy ez a szerény jövedelmi adottságokkal rendelkező csoport 
a legkisebb mértékben (15 százalék) tud csak részesedni a 10 millió forintos közvetlen állami támogatásból, hiszen a családi házak esetében minimális, a lakásoknak pedig 41 százaléka új ingatlan. Az új ingatlanok több mint fele (54 százalék) falun talál gazdára (11. táblázat), alacsonyabb árszínvonaluk miatt. Ennek a csoportnak nagy szüksége van a támogatásra, mert még azzal is csak a legszerényebb hajlékot engedhetik meg maguknak. Az egy főre jutó közvetlen, vissza nem térítendő állami támogatás mértéke 3,1 millió forint, ami a második legalacsonyabb értéket képviseli a többi csoporthoz viszonyítva.

\section{1. táblázat}

Csoportok az ingatlan jellemzői szerint

$$
\begin{array}{l|l|l|l|l|l|l|}
\text { 1. csoport } & \text { 2. csoport } & \text { 3. csoport } & \text { 4. csoport } & \text { 5. csoport } & \text { 6. csoport } & \text { 7. csoport } \\
\hline
\end{array}
$$

Az ingatlan (ház/lakás) jellege szerinti eloszlás (db, \%)

\begin{tabular}{l|c|c|c|c|c|c|c}
\hline Ház $(\mathrm{db})$ & 60 & 69 & 43 & 25 & 5 & 0 & 21 \\
\hline Új házak & $15 \%$ & $38 \%$ & $33 \%$ & $64 \%$ & $0 \%$ & $0 \%$ & $71 \%$ \\
\hline Használt házak & $85 \%$ & $62 \%$ & $67 \%$ & $36 \%$ & $100 \%$ & $0 \%$ & $29 \%$ \\
\hline Lakás $(\mathrm{db})$ & 82 & 10 & 44 & 1 & 1 & 6 & 41 \\
\hline Új lakások & $41 \%$ & $60 \%$ & $73 \%$ & $100 \%$ & $0 \%$ & $50 \%$ & $100 \%$ \\
\hline Használt lakások & $59 \%$ & $40 \%$ & $27 \%$ & $0 \%$ & $100 \%$ & $50 \%$ & $0 \%$ \\
\hline
\end{tabular}

Településtípus, valamint az ingatlan jellege és minősége szerinti eloszlás (\%, db)

\begin{tabular}{l|c|c|c|c|c|c|c}
\hline FALU & $49 \%$ & $18 \%$ & $62 \%$ & $50 \%$ & $50 \%$ & $50 \%$ & $12 \%$ \\
\hline használt $(\mathrm{db})$ & 47 & 4 & 28 & 9 & 3 & 2 & 3 \\
\hline új $(\mathrm{db})$ & 23 & 10 & 16 & 4 & 0 & 1 & 0 \\
\hline VÁROS & $51 \%$ & $82 \%$ & $38 \%$ & $50 \%$ & $50 \%$ & $50 \%$ & $88 \%$ \\
\hline használt $(\mathrm{db})$ & 52 & 43 & 13 & 0 & 3 & 1 & 3 \\
\hline új $(\mathrm{db})$ & 20 & 22 & 20 & 13 & 0 & 2 & 19 \\
\hline
\end{tabular}

Hasznos alapterület szerinti eloszlás (\%)

\begin{tabular}{l|c|c|c|c|c|c|c}
\hline $60 \mathrm{~m}^{2}$ alatt & $9 \%$ & $8 \%$ & $7 \%$ & $0 \%$ & $0 \%$ & 0 & $0 \%$ \\
\hline $61-70 \mathrm{~m}^{2}$ & $8 \%$ & $1 \%$ & $10 \%$ & $0 \%$ & $0 \%$ & 0 & $0 \%$ \\
\hline $71-80 \mathrm{~m}^{2}$ & $30 \%$ & $1 \%$ & $26 \%$ & $0 \%$ & $17 \%$ & 6 & $0 \%$ \\
\hline $81-90 \mathrm{~m}^{2}$ & $26 \%$ & $11 \%$ & $11 \%$ & $0 \%$ & $0 \%$ & 0 & $12 \%$ \\
\hline $91-100 \mathrm{~m}^{2}$ & $18 \%$ & $15 \%$ & $26 \%$ & $12 \%$ & $50 \%$ & 0 & $4 \%$ \\
\hline $101-110 \mathrm{~m}^{2}$ & $3 \%$ & $18 \%$ & $2 \%$ & $12 \%$ & $0 \%$ & 0 & $0 \%$ \\
\hline $111-120 \mathrm{~m}^{2}$ & $2 \%$ & $10 \%$ & $3 \%$ & $15 \%$ & $0 \%$ & 0 & $0 \%$ \\
\hline $121-140 \mathrm{~m}^{2}$ & $0 \%$ & $10 \%$ & $5 \%$ & $19 \%$ & $0 \%$ & 0 & $8 \%$ \\
\hline $141 \mathrm{~m}^{2} \mathrm{felett}$ & $4 \%$ & $25 \%$ & $8 \%$ & $42 \%$ & $33 \%$ & 0 & $76 \%$ \\
\hline
\end{tabular}

A 2. csoport 21 százalékos részesedést képvisel, amivel a harmadik legnépesebb csoportnak számít (10. táblázat). Ebben a csoportban a legmagasabb (71 százalék) a nagycsaládosok aránya. Átlagban 580 ezer forintos családi jövedelem mellett 
40 millió forintos ingatlanokat vásárolnak első ingatlanként (4. ábra). Ezek jellemzően a 90-110 m² feletti kategóriába tartoznak, de az ennél nagyobb ingatlanok eloszlása is egyenletes (11. táblázat). A családok 11 százaléka rendelkezik korábbi lakóingatlannal (10. táblázat). Náluk a harmadik legmagasabb (a 4. és az 1. csoport után) a gyermek előrevállalási kedv. Az igénylők 54 százaléka városi használt házak mellett kötelezte el magát (11. táblázat). A 3. és a 4. csoporthoz hasonlóan itt is magas (53 százalék) a két hitellel rendelkezők aránya. Átlagosan 14 millió forintos piaci hitel felvételét vállalják a kamattámogatott hitelen túlmenően, ami az összes csoport közül a legmagasabb értéket képviseli. A csoport tagjai 20 százalékban tudnak élni a 10 millió forintos közvetlen támogatással, hiszen ők jellemzően városi használt házakat keresnek. A csoportban az egy főre jutó közvetlen vissza nem térítendő állami támogatás mértéke 3,5 millió forint, ami a harmadik legalacsonyabb érték a többi csoporthoz képest.

Ők számítanak a középkategóriának mind a jövedelem, mind az ingatlan tekintetében, a városi házért pedig nagyobb eladósodottságot is vállalnak (jövedelmi helyzetük ezt lehetővé teszi). Az igénylők 38 százaléka vásárol új házat (11. táblázat), a 4. csoportban pedig a családok 36 százaléka vesz használtat. A két csoport között az a különbség, hogy a 2. csoport magasabb jövedelem és nagyobb eladósodottság mellett kisebb városi házakat, lakásokat vásárol, míg a 4. csoport tagjai falusi környezetben tágasabb új ingatlanokat. Ezen csoportoknál jól megmutatkozik a város többletköltsége a faluval szemben.

A 3. csoportba az igénylők 23 százaléka tartozik (10. táblázat). A nagycsaládosok 66 százalékos részesedéssel rendelkeznek, amivel a második legnépesebb nagycsaládos csoportnak számítanak. Középkategóriásnál magasabb jövedelemmel rendelkeznek, és alacsonyabb értékü, jellemzően 90-100 m² házakat és $60-80 \mathrm{~m}^{2}$ lakásokat vásárolnak (11. táblázat). Az igénylők 52 százaléka a támogatott hiteleken túl is felvesz - átlagosan 7,5 millió forint piaci kamatozású - hitelt.

Ebben a csoportban a legmagasabb a falusi ingatlanok aránya (62 százalék), ami az új ingatlanok részarányának csökkenését eredményezi (11. táblázat). A falura költözők a használt házak, a városi ingatlanok esetében pedig az új építésű lakások kelendőbbek ezen családok körében. Az igénylők közt 17 százalék azok aránya, akik ezzel a támogatással már nem az első ingatlanjukhoz jutnak hozzá (10. táblázat). Stabil egzisztenciájuk mellett ez a csoport rendelkezik a legtöbb (33 százalék) igénylővel, aki a legmagasabb 10 millió forintos közvetlen támogatási összegben részesült. Ezért cserébe azonban nem köteleződnek el jelentősebb mértékben (18 százalék) további gyermek vállalására. A csoportban az egy före jutó közvetlen, vissza nem térítendő állami támogatás mértéke 4,7 millió forint, ami a legmagasabb a többi kategóriához képest annak ellenére, hogy a jövedelmi szintje nem ennek a csoportnak a legalacsonyabb. 
A 4. csoportba az igénylő családok 7 százaléka tartozik (10. táblázat), akik alacsony jövedelmi szint mellett átlagot meghaladó mértékű - jövedelmi szintjükhöz viszonyítva magas értékü - 46 millió forintos ingatlanokat vásárolnak (4. ábra). A gyermek-előrevállalás a csoportot alkotók felére (54 százalék) jellemző, ami az összes csoport közt a legmagasabb. Ezt a jövedelem és a megvásárolni kívánt ingatlan közti különbség is kedvezően befolyásolhatja. A támogatott hitelen túli eladósodottság mértéke átlagosan 8,3 millió forint. Két hitellel a családok 46 százaléka rendelkezik.

A csoport majdnem minden tagja családi házat vásárol, a két gyermekesek pedig mindannyian új ingatlant (11. táblázat). Erre a csoportra - a 7. csoporthoz hasonlóan - szintén jellemző az új ingatlan vásárlása. Jövedelmi helyzetükből adódóan az igénylők majdnem fele (46 százaléka) inkább falura költözik, tágas otthont teremtve ezzel a családja számára. A vásárolt ingatlanok $90 \mathrm{~m}^{2}$ felettiek, de szép számban (35 százalék) tulajdonolnak $151 \mathrm{~m}^{2}$ feletti ingatlanokat is (11. táblázat). A 10 millió forintos legmagasabb támogatási összeget a csoport 19 százaléka tudja felvenni. A csoportban az egy före jutó közvetlen, vissza nem térítendő állami támogatás mértéke 3,8 millió forint, ami a harmadik legmagasabb a többi csoporthoz képest.

Esetükben feltételezhetjük, hogy a gyermek előrevállalását részben az ingatlanszerzés indukálta, hiszen a legmagasabb előrevállalási hajlandóság alacsony jövedelemmel és nagy értékű ingatlannal párosul. A 10 millió forintos támogatást azonban csak kevesen tudták kihasználni, pedig magas a nagycsaládok száma. Megítélésünk szerint ők a támogatás nélkül nem tudtak volna ilyen értékű ingatlant megvásárolni - korábbi ingatlannal nem rendelkeztek, hiszen magas ingatlanár mellett is jelentős az ingatlan hitellel való terheltsége. Ezt a csoportot jellemzi leginkább a gyermek előrevállalása. Mégsem itt történik meg a legnagyobb támogatási összegek kifizetése, pedig jövedelmi helyzetük alapján indokolt lenne.

Az 5. csoportba kevés család, mindössze a hitelfelvevők 2 százaléka tartozik (10. táblázat). A túlnyomó részt (67 százalék) nagycsaládosok által alkotott csoport minden tagja a legmagasabb jövedelmi kategóriába tartozik. Jellemzően 90-100 m² nagyságú és $141 \mathrm{~m}^{2}$ feletti (11. táblázat) hasznos alapterületű használt házakat (11. táblázat) vásárolnak második ingatlanként (mindössze egy igénylő valósított meg minőségi lakáscserét), 37 millió forintos átlagár mellett (4. ábra).

Ők korábban már rendelkeztek egy lakással, melyet a támogatással vásárolt ingatlan ellenére is megtartottak (10. táblázat). A közvetlen támogatáson túl teljes mértékben igénybe veszik a kamattámogatott hitelt. A kétgyermekes családok (50 százalék) az igényléskor még nem voltak jogosultak a kamattámogatott hitel felvételére, ezért ők piaci hitellel adósodnak el. További gyermeket a csoport egyik tagja sem vállal. A csoportban az egy főre jutó közvetlen, vissza nem térítendő állami támogatás mértéke 1,9 millió forint, ami a legalacsonyabb a többi csoporthoz viszonyítva. Ók a támogatások maximális kihasználása és minimális további eladósodottság mellett 
egzisztenciájuk növelését érik el ezzel az újabb ingatlannal, további gyermek vállalása nélkül. 2016-ban és 2017-ben a korábbi ingatlantulajdon megléte miatt ezen csoportok nem élhettek volna a kedvezménnyel.

A 6. csoportba az igénylők csak kis része, 2 százaléka tartozik (10. táblázat). A csoporton belül a családméret szerinti megoszlás kiegyenlített, a gyermek előrevállalásának mértéke 33 százalék. A családok mindegyike maximálisan kihasználta a közvetlen állami támogatást, és a kamattámogatott hitelt is lehívta, amit már nem egészített ki további piaci hitellel. Az általuk megvásárolt ingatlanok 30 millió forint alatti 70-80 m² (11. táblázat) közötti hasznos alapterülettel rendelkező lakások. Az igénylők, bevallásuk alapján, korábban nem rendelkeztek saját tulajdonú ingatlannal, bár a vizsgált minta viszonyában itt a legmagasabb a rendelkezésre álló családi jövedelem (10. táblázat). Esetükben ugyanis 1 millió forintos jövedelemhez (4. ábra) a legkisebb értékű ingatlanok tartoznak, melyek mindegyike lakástulajdon (11. táblázat). A csoportban az egy före jutó közvetlen vissza nem térítendő állami támogatás mértéke 4,6 millió forint, ami a második legmagasabb az egyes kategóriák viszonyában.

Véleményünk szerint ez az ingatlan inkább egy második otthon vásárlását jelentheti, melyhez jó lehetőséget teremtett az igénybe vehető állami támogatás, növelve ezzel ezen családok amúgy is stabil egzisztenciális helyzetét. A kedvező anyagi körülményeik, a támogatási elemek kihasználása és további, egyéb hitel felvételének hiánya jelzi, hogy számukra nem volt feltétlenül szükséges a támogatás az ingatlantranzakció megfinanszírozásához. A támogatás nélkül azonban ezek a háztartások nem biztos, hogy belevágtak volna egy ingatlanberuházásba. Ennél a csoportnál a támogatás ingatlanösztönző képessége jól megmutatkozik, további gyermekvállalást azonban várhatóan nem generál.

A 7. csoportba a családok 7 százaléka tartozik (10. táblázat). Ők vásárolják meg a legnagyobb, 65 millió forint feletti értékkel rendelkező ingatlanokat, melyhez magas (átlag 867 ezer forintos) jövedelem társul (4. ábra). Azok az igénylők, akik korábban már rendelkeztek ingatlannal, értékesítették azt, és az értékesítéssel realizált bevételt felhasználták az új ingatlan megszerzéséhez. A nagycsaládosok részaránya ebben a csoportban a legalacsonyabb (40 százalék), a gyermek előrevállalási hajlandóság pedig 36 százalék. Egy igénylő kivételével mindenki jogosult volt már a kamattámogatott hitel felvételére, melyet maximális mértékben ki is használtak. A csoportban az egy főre jutó közvetlen, vissza nem térítendő állami támogatás mértéke 3,7 millió forint, ami a negyedik legmagasabb a többi csoporthoz képest. A csoport tagjainak igen kedvező lehetőséget biztosított a kamattámogatott hitel kiterjesztése a kétgyermekes családokra. Ezt igazolja, hogy a kétgyermekes családok egy kivételével már csak a kamattámogatott hitel igénybevehetősége után vágtak bele az ingatlanvásárlásba. Ez jelentősen csökkentette a piaci hitellel való terheltségüket, ezáltal pedig az adósságszolgálatot. A megvásárolt ingatlanok esetében 
a lakások már nagyobbak $\left(80 \mathrm{~m}^{2}\right)$, a családi házak 48 százaléka pedig $171 \mathrm{~m}^{2}$ feletti hasznos alapterülettel rendelkezik (11. táblázat). Az igénylők 16 százaléka volt jogosult a legmagasabb, 10 millió forintos vissza nem térítendő állami támogatás felvételére, mely esetükben pozitív hozadékként gyermek-előrevállalással nem párosult. A városban élők száma ebben a csoportban a legmagasabb (88 százalék), és szintén jelentős az új ingatlant vásárlók száma is (11. táblázat).

Elemzésünk alapján így az igénylők egyes csoportjait a következőképp neveztük el és jellemeztük (4. ábra):

1) Használt lakást vásárló, rászoruló kiscsaládok - legalacsonyabb jövedelemmel legolcsóbb ingatlanárral - magas gyermekvállalás nélkül

2) Városi használt ház vásárlója, nagycsaládosok - közepes jövedelemmel - közepes ingatlanárral - magas gyermek-előrevállalással

3) Felső középrétegbe tartozó nagycsaládosok - a 10 millió forintot kihasználók közepesen magas jövedelemmel - szerényebb ingatlan mellett - alacsony további gyermek-előrevállalás mellett

4) Falusi új házat vásárlók - alacsonyabb jövedelemmel - magas ingatlanárral a legmagasabb gyermek-előrevállalással

5) Befektetési házvásárlók, a korábbi lakás mellé - magas jövedelemmel - közepes ingatlanárral - további gyermekvállalás nélkül

6) Befektetési lakásvásárlók - magas jövedelemmel - alacsony ingatlanárral - további gyermekvállalás nélkül

7) Városi új luxusházban élő kiscsaládok - magas jövedelemmel - legmagasabb ingatlanárral - további gyermekvállalás nélkül

\section{5. Összefoglalás és következtetések}

Az ország nyugati és középső régióiban anonim hitelintézeti adatbázis segítségével lefolytatott vizsgálatunk alapján a támogatást igénylők 44 százaléka a kétgyermekes, 43 százaléka a nagycsaládos családmodellt választotta. A gyermek-előrevállalási hajlandóság 23 százalék, ami ugyan némiképp alacsonyabb, mint az országos 33 százalék, de az előrevállalt gyermekek számában és a választott családméret tekintetében sem állapítható meg számottevő különbség. A vizsgált régiókban a gyermeket előre vállalók 68 százaléka kétgyermekes családmodell mellett kötelezte el magát. A gyermek-előrevállalás nagy jelentőséggel bír, hiszen esetükben fennáll annak a lehetősége, hogy a korábban tervezett gyermeknél többet vállalnak, támogatva ezzel a kormány demográfiai céljainak megvalósulását. A jövőbeni gyermek megszületését 
vállalók több mint fele további egy gyermeket vállal. A három gyermeket előre vállalók száma minimális, 2 százalék.

Az új ingatlant vásárló, gyermeket előre vállalók 17 százaléka nagycsaláddá, 38 százaléka kétgyermekes családdá szeretne bővülni. A gyermeket előre vállalók körében - a nagycsaládos és a kétgyermekes családmodell elkötelezettjei - közel azonos mértékben, fele-fele arányban vásárolnak a támogatásból új és használt ingatlant. Ebből arra következtetünk, hogy a magas, 10 millió forintos támogatási összeg nem ösztönözte jelentősen a családokat arra, hogy nagycsaládosak legyenek, és emellett új ingatlanberuházásba kezdjenek. A gyermekvállalást sokkal inkább a támogatás megléte ösztönözte. Ezen állításunkat erősíti, hogy országos szinten is közel azonos mértékű gyermek-előrevállalás figyelhető meg az új és a használt ingatlant választók körében. A kormány demográfiai célkitűzéseit legkevésbé azon nagycsaládosok (14 százalék) támogatják, akik meglévő gyermekeiken túl már nem vállalnak további gyermeket, és a támogatást új ingatlan vásárlására fordítják.

A támogatás felső jövedelmi korlát nélküli igénybevételének lehetősége az igénylők 8 százalékát második ingatlan megvásárlására sarkallta. Ezen igénylők számát a 2019-ig még érvényben lévő, 50 százalékot meghaladó ingatlantulajdon meglétére vonatkozó korlátozások újbóli és teljes körü (új ingatlanokra is kiterjedő) alkalmazása csökkenthetné. Ennek okán egyetértünk Banai és szerzőtársai (2019) javaslatával, miszerint célszerű lenne a támogatási feltételek ez irányú felülvizsgálata.

A hitelt felvevő igénylők családi jövedelme és ingatlanérték szerinti csoportokba rendezése alapján 7 egymástól elkülönülő csoport alakult ki. A vizsgálat alapján megállapítjuk, hogy az 1. csoport rendelkezik a legkisebb jövedelem és ingatlanár kombinációval, magas gyermek-előrevállalási hajlandóság mellett. Számukra nem megfizethető a jó minőségű, új ingatlan, ezért esetükben ítéltük meg a támogatást a legszükségesebbnek az otthonteremtés elősegítésében. A kifizetett támogatási összegekből kis mértékben részesülnek annak ellenére, hogy szociális alapon ez a csoport szorul rá leginkább a támogatásra. Helyzetükön a 10 millió forintos támogatás felvehetősége sem segít, ugyanis abból a kisebb családméret és a használt ingatlan vásárlása miatt csak korlátozottan részesülhetnek.

A gyermek-előrevállalási hajlandóság nagyobb az alacsonyabb jövedelmi szintekkel rendelkező csoportokban (1., 2. és 4.). Szintén ezen csoportokra jellemző a kisebb támogatási összegek lehívása, az agglomerációba, falura való költözés, a családi házak iránti nagyobb érdeklődés mellett. A legtöbb állami támogatást a 3. csoport mondhatja magáénak, közepesen magas jövedelmi szintjük ellenére. Három csoportot (5., 6. és 7.) azonosítottunk, akiknél nem tartjuk szükségszerűnek, hogy állami támogatás felhasználásával meglévő ingatlanjuk mellé újabbat szerezzenek, amivel még előnyösebb helyzetbe kerülnek a többi igénylőhöz képest. 
A támogatási rendszernek azonban vitathatatlan előnye a családoknak és a használt lakás szerzésének támogatása. A nagycsaládosok támogatása minden eddigi lakástámogatási rendszerben kiemelt figyelmet kapott, de ez idáig egyik időszakban sem öltött ilyen méreteket. Ezért a jövőben célul tűzzük ki annak vizsgálatát, hogy az előre vállalt gyermek után támogatást igénylők mekkora részét ösztönözte az addicionális gyermekvállalásra.

A támogatás gazdaságélénkítő, munkahelyteremtő hatása és az iránta való jelentős érdeklődés miatt törekedni kell annak hosszú távú fenntarthatóságára, hiszen az hozzájárul a családok lakásberuházásának tervezhetőségéhez. Ennek érdekében megfontolandó a gyermekszámtól függő támogatási összegek harmonizációja, az ingatlanhalmozás lehetőségének kizárása és felső jövedelmi korlát beépítése. Azért, hogy a lakáspolitikai célok beváltsák a népesedés terén hozzá füzött reményeket, nem elegendő csak a támogatásokkal segíteni a lakáshoz jutást, továbbra is kedvező és stabil makrogazdasági környezetet kell bizotsítani. Ezért egyértelműen megerősítjük azokat a korábbi kutatási eredményeket, amelyek a családpolitikai támogatásoknál a kiszámíthatóságot és a céltudatosságot hangsúlyozzák.

\section{Felhasznált irodalom}

Banai Ádám - Danila Pankov - Fábián Gergely - Nagy Tamás (2019): Hogyan alakította át a CSOK a hazai lakás- és hitelpiacot? Szakmai cikk, Magyar Nemzeti Bank.

Beaujouan, E. - Sobotka, T. - Brzozowska, Zs. - Zeman, K. (2017): Has childlessness peaked in Europe? Population \& Societies, No. 540(January): 1-4.

Békés Gábor - Horváth Áron - Sápi Zoltán (2016): Lakóingatlanárak és települési különbségek. Közgazdasági Szemle, 63(december): 1289-1323. http://dx.doi.org/10.18414/ KSZ.2016.12.1289

Bényei Zoltán (2011): Javaslat a lakásfenntartást segítő támogatások átalakitására. Kapocs, 10(2): 1-25.

Csermák Károly (2011): Quo Vadis, magyar lakáspolitika? Polgári Szemle, 7(1): 43-62.

Dániel Zsuzsa (1997): Lakástámogatás és társadalmi újraelosztás. Közgazdasági Szemle, 44(október): 848-877.

Dániel Zsuzsa (2004): Állam és piac - lakástámogatás, lakásfinanszírozás, reformok. Nemzetközi tapasztalatok. Közgazdasági Szemle, 51(február): 139-152. 
Dorbritz, J. - Ruckdeschel, K. (2007): Kinderlosigkeit in Deutschland. Ein europäischer Sonderweg? Daten, Trends und Gründe. In: Konietzka, D. - Kreyenfeld, M. (Eds.): Ein Leben ohne Kinder. VS Verlag für Sozialwissenschaften, Wiesbaden, pp. 45-81. https:// doi.org/10.1007/978-3-531-90323-1_2

Elek Zsuzsanna - Szikra Dorottya (2018): Fordított újraelosztás a lakáspolitikában: a CSOK versengő céljai. Új Egyenlőség. https://ujegyenloseg.hu/forditott-ujraelosztas-alakaspolitikaban-a-csok-versengo-celjai/. Letöltés ideje: 2020. május 16.

Fitoussi, J.P. - Sen, A. - Stiglitz, E.J. (2008): Report by the Commission on the Measurement of Economic Performance and Social Progress. Chapter 2: 1-292. https://ec.europa.eu/ eurostat/documents/8131721/8131772/Stiglitz-Sen-Fitoussi-Commission-report.pdf. Letöltés ideje: 2021. február 9.

Hegedűs János (2006): Lakáspolitika és lakáspiac, a közpolitika korlátai. Magyar Valóság, 2006(5): 1-36.

Horváthné Kökény Annamária - Tóth Flóra (2017): A családok otthonteremtési kedvezménye a családok szemszögéböl. Gradus, 4(2): 528-533.

Kapitány Balázs - Spéder Zsolt (2018): Gyermekvállalás. In: Monostori Judit - Őri Péter Spéder Zsolt (szerk.): Demográfiai Portré 2018. Jelentés a magyar népesség helyzetéről. KSH Népességtudományi Kutatóintézet, Budapest, pp. 47-64.

Kiss Gergely - Vadas Gábor (2006): A lakáspiac szerepe a monetáris transzmisszióban. Közgazdasági Szemle, 53(május): 408-427.

KINCS (2019): Családi Otthonteremtési Kedvezmény (CSOK) szerződéseinek elemzése a 20162017-2018. évi adatok alapján. Kopp Mária Intézet a Népesedésért és a Családokért, Budapest, pp. 1-75. https://www.koppmariaintezet.hu/docs/CSOK2_vegso1.0_honlap_ form.pdf. Letöltés ideje: 2021. április 19.

KINCS (2020a): Családi Otthonteremtési Kedvezmény igénybevétele 2019 július és 2020 június között elemzés. Kutatási Iroda, Szakpolitikai Elemző Iroda, Kopp Mária Intézet a Népesedésért és a Családokért, Budapest, pp. 1-10. https://www.koppmariaintezet. hu/docs/CSOK_2019jul_2020jun_KINCS.pdf. Letöltés ideje: 2021. február 09.

KINCS (2020b): Egy éves a Családvédelmi Akcióterv 2020. július 1. Kopp Mária Intézet a Népesedésért és a Családokért, Budapest, pp. 1-16. https://www.koppmariaintezet. hu/docs/1eves_a_Csaladvedelmi_Akcioterv_Sajtotajekoztato.pdf. Letöltés ideje: 2021. február 09. 
Kováts Bence (2007): Az önkormányzati hatáskörbe került lakhatási támogatások vizsgálata 31 önkormányzat példáján. Habitat for Humanity Magyarország. https://www.habitat. hu/files/Onkormanyzati_lakhatasi_tamogatasok_Habitat_0720.pdf. Letöltés ideje: 2020. július 23.

KSH (2012a): A családok családösszetétel és a gyermekek száma szerint. Központi Statisztikai Hivatal. http://www.ksh.hu/nepszamlalas/tablak_haztartas. Letöltés ideje: 2021. május 24.

KSH (2012b): A lakott lakások tulajdonjelleg, alapterület, épitési év és településtípus szerint, 2011. Központi Statisztikai Hivatal. https://www.ksh.hu/nepszamlalas/tablak_ lakasviszonyok. Letöltés ideje: 2021. május 24.

KSH (2016): Lakáshelyzet és gyermekvállalás: fontos, de nem a legfontosabb. A CSOK termékenységi hatásairól. Demografia.hu/Korfa, 16(1): 1-4. https://www.demografia. hu/kiadvanyokonline/index.php/korfa/article/view/2652

KSH (2018a): Fejlettségi szint (2003-2018). Központi Statisztikai Hivatal. https://www.ksh. hu/thm/1/indi1_1_4.html. Letöltés ideje: 2021. május 24.

KSH (2018b): Lakossági lakáshitelezés, 2017. KSH Statisztikai Tükör, Központi Statisztikai Hivatal, április 13. https://www.ksh.hu/docs/hun/xftp/idoszaki/lakashitel/lakashitel1712. pdf. Letöltés ideje: 2021. május 24.

KSH (2020a): Egy före jutó bruttó és nettó jövedelem régió és településtípus szerint. Központi Statisztikai Hivatal. http://www.ksh.hu/stadat_files/jov/hu/jov0045.html. Letöltés ideje: 2021. május 24.

KSH (2020b): Munkanélküliségi ráta. Központi Statisztikai Hivatal. https://www.ksh.hu/docs/ hun/xstadat/xstadat_evkozi/e_qlf027h.html. Letöltés ideje: 2021. május 24.

KSH (2021a): Lakossági lakáshitelezés, 2020. I. félév. Központi Statisztikai Hivatal. http:// www.ksh.hu/docs/hun/xftp/idoszaki/lakashitel/20201/index.html. Letöltés ideje: 2021. április 24 .

KSH (2021b): A népesség, népmozgalom föbb mutatói. Központi Statisztikai Hivatal. http:// www.ksh.hu/stadat_files/nep/hu/nep0001.html. Letöltés ideje: 2021. április 24.

Levi, M. (1993): The Construction of Consent. Administration, Compliance and Governability Program, Australian National University, Canberra.

Lesthaeghe, R. (2011): The "second demographic transition": a conceptual map for the understanding of late modern demographic developments in fertility and family formation. Historical Social Research, 36(2): 179-218. https://doi.org/10.12759/hsr.36.2011.2.179218 
Mayo, S. K. - Angel, S. (1993): Housing: Enabling Markets to Work. A World Bank Policy, Washington, D.C., pp. 1-167. https://documents1.worldbank.org/curated/ en/387041468345854972/pdf/multiOpage.pdf. Letöltés ideje: 2020. november 6 .

Mádi László (2008): Lakáspolitika - otthonteremtés: Történések és tapasztalatok a közelmúlt magyarországi időszakából. PhD értekezés, Nyugat-Magyarországi Egyetem. http://www. nyme.hu/fileadmin/dokumentumok/ktk/Kepzes_doktori/2008/2008_MadiLaszlo_d.pdf. Letöltés ideje: 2020. február 1.

Mádi László (2017): Egy kívánatos és reális lakáspolitikai körvonalai Magyarországon 2017ben. Acta Wekerleensis, 2017(1): 1-20.

Maleque, M. (2019): For us, family is also first. Budapesti Demográfiai Csúcs. https://csalad. hu/tamogatasok/zahid-maleque-for-us-family-is-also-first. Letöltés ideje: 2021. január 10.

MNB (2020): Lakáspiaci jelentés 2020. november. Magyar Nemzeti Bank. https://www.mnb. hu/kiadvanyok/jelentesek/lakaspiaci-jelentes/lakaspiaci-jelentes-2020-november. Letöltés ideje: 2021. február 13.

Neyer, G. - Thévenon, O. - Monfardini, C. (2016): Policies for Families: Is there a Best Practice? Families and Societies. European Policy Brief, pp. 1-12. http://www.familiesandsocieties. eu/wp-content/uploads/2016/12/policy_brief_5.pdf. Letöltés ideje: 2020. szeptember 5.

Novák Katalin (2020): A magyar családpolitikának kettős célja van. https://csalad.hu/ tamogatasok/a-magyar-csaladpolitikanak-kettos-celja-van. Letöltés ideje: 2021. január 10.

Obádovics Csilla (2009): Klaszteranalízis. Eszterházy Károly Főiskola, Eger.

Papházi Tibor - Fail Ágnes - Horváth-Varga Anikó (2021): A Családi Otthonteremtési Kedvezmény 2020. évi eredményei. Gyorsjelentés. Kopp Mária Intézet a Népesedésért és a Családokért, Budapest, pp. 1-16. https://www.koppmariaintezet.hu/docs/CSOK_2020_ gyorsjelentes_2021_03_05.pdf. Letöltés ideje: 2021. április 16.

Rothstein B. (1998): Just Institutions Matter. The Moral and Political Logic of the Universal Welfare State. Cambridge University Press, Cambridge, pp. 1-254. https://doi. org $/ 10.2307 / 2585870$

Sági Judit - Tatay Tibor - Lentner Csaba - Neumanné Virág Ildikó (2017): A család- és otthonteremtési adókedvezmények, illetve támogatások egyes hatásai. Pénzügyi Szemle, 2017(2): 173-189.

Sági Judit - Lentner Csaba (2020): A magyar népességpolitikai intézkedések tényezői és várható hatásai. Közgazdasági Szemle, 67(március): 289-308. https://doi.org/10.18414/ KSZ.2020.3.289 
Singhammer, J. (2019): A family gives you a home and boosts the abilities of children. Budapesti Demográfiai Csúcs. https://csalad.hu/tamogatasok/johannes-singhammer-afamily-gives-you-a-home-and-boosts-the-abilities-of-children. Letöltés ideje: 2021. január 10.

Sobotka, T. (2017): Childlessness in Europe: Reconstructing Long-Term Trends Among Women Born in 1900-1972. In: Kreyenfeld, M. - Konietzka, D. (eds.): Childlessness in Europe. Contexts, Causes, and Consequences, Demographic Research Monographs, pp. 17-53. https://doi.org/10.1007/978-3-319-44667-7_2

Spéder Zsolt - Murinkó Lívia - Oláh Sz. Lívia (2017): Sailing close to the wind? The effects of third birth policies in post-communist Hungary. Working Papers on Population, Family and Welfare, 27. Hungarian Demographic Research Institute, Budapest. https://doi. org/10.21543/WP.2017.27

Székely Gáborné (2020): Száz év a magyarországi lakásstatisztikában. Statisztikai szemle, 98(6): 642-664. https://doi.org/10.20311/stat2020.6.hu0642

Szikra Dorottya (2016): Nem azoknak segít a CSOK, akiknek a legnagyobb szükségük lenne rá. http://lumens.hu/2016/03/02/nem-azoknak-segit-a-csok-akiknek-a-legnagyobb-szukseguklenne-ra/. Letöltés ideje: 2020. december 11.

Tatay Tibor - Sági Judit - Lentner Csaba (2019): A családi otthonteremtési kedvezmény költségvetési terheinek elöreszámítása 2020-2040. Statisztikai Szemle, 97(2): 192-212. https://doi.org/10.20311/stat2019.2.hu192

Tóth Flóra - Horváthné dr. Kökény Annamária (2018): A családok otthonteremtési kedvezménye és annak várható hatásai (The Family Housing Allowance and the Effects Expected). Economica New, 9(2): 55-63. https://doi.org/10.47282/ ECONOMICA/2018/9/2/4134 